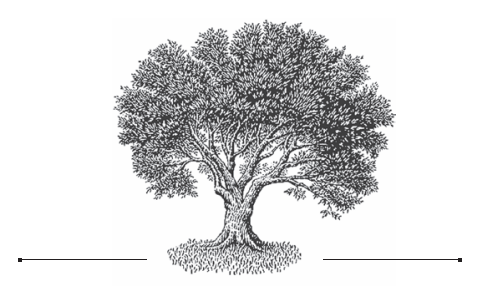

\section{Первая сербская}

\section{писательница:}

Из истории

женской литературы

начала XIX века

\section{Илья Юрьевич Виницкий}

Принстонский университет

Принстон, США
The First Serbian

Female Writer:

From the History of

Nineteenth-Century

Women's Literature

\author{
Ilya Yu. Vinitsky \\ Princeton University \\ Princeton, USA
}

\title{
Резюме
}

В конце XIX в. в сербский национальный дитературный пантеон был введен романтический образ Евстахии Арсич (Еустахија Арсић, 1776-1843) как первой сербской писательницы и философки нового времени. Этот образ основывается прежде всего на книге Арсич «Полезная размышленія о четырехъ годишнихъ временехъ», вышедшей в Будиме в 1816 г. с указанием имени сочинительницы. Во второй половине XX в. жизни и творчеству Арсич были посвящены несколько научных статей и литературная биография. В последние годы этот образ привлек к себе внимание исследователей женской литературы в южно-славянских странах. Исследователи творчества Арсич указывают, что ее «Размышления» написаны под вдиянием

* Автор выражает глубокую признательность М. Г. Альтшуллеру, Татьяне Артемьевой, Маргарет Бэйсинждер, Адриану Вэннеру, Майклу Вахтелю, Дэвиду Куперу, Маркусу Левиту, Ирэне Лукшич, С. И. Николаеву и А. И. Рейтблату за ценные советы и замечания.

\footnotetext{
Цит ирование: Виницкий И. Ю. Первая сербская писательница: Из истории женской литературы начала XIX века // Slověne. 2019. Vol. 8, № 1. C. 284-327.

Citation: Vinitsky I. Yu. (2019) The First Serbian Female Writer: From the History of Nineteenth-Century Women's Literature. Slověne, Vol. 8, № 1, p. 284-327.

DOI: $10.31168 / 2305-6754.2018 .7 .2 .11$
} 
западной предромантической (сентиментальной) литературы, освещают широкую проблематику на границе философии, этики, истории, естественных наук, анатомии, физики и религии и вводят в сербскую литературу жанр феминистического эссе. Стихотворения, вошедшие в «Размышления», печатаются в антологиях сербской литературы как оригинальные.

В настоящей статье показывается, что представления об оригинальности, европейской образованности, космополитизме, личном тоне, философском даре и поэтическом таланте Евстахии Арсич сильно преувеличены и что ее авторский образ явдяется культурным конструктом, созданным на определенном этапе формирования сербской национальной литературы и востребованным и переосмысленным в более позднее время. В работе установлено, что «Полезная размышления» Арсич являются компиляцией статей, трактатов и стихотворений, опубликованных в российских журналах и сборниках конца 1780-х - начала 1810-х гг. Эти произведения (включая несколько сочинений Н. М. Карамзина) были перенесены в книгу с минимальными орфографическими и грамматическими изменениями (например, замена мужского рода оригинала на женский) и без указания на источники. Работа составителя «Размышлений» в целом свелась к тому, чтобы «христианизировать», «авторизовать», «национадизировать» и «феминизировать» переведенные российскими авторами сентиментальные тексты. Предложенные в работе наблюдения и размышления не только устанавливают прямые источники «славяно-русской» книги «первой сербской писательницы» и описывают процесс усвоения и присвоения «чужого» как стадию национадьного и литературного самоутверждения «молодой» родственной культуры, но и дают материал для более общего - филологического и литературоведческого - исследования «славяно-русского» периода в истории сербской дитературы в частности и «панславянского» предромантизма в целом. Случай Арсич представляет интерес и для сравнительного исследования формирования национальных авторских «пантеонов» и гендерной истории русской и других славянских литератур.

\section{Ключевые слова}

Евстахия Арсич, сербская литература, русский сентиментализм, Карамзин, проблема перевода, национализм, женская литература, «феминизация», мистификация

\section{Abstract}

At the end of the nineteenth century the Romantic image of Eustahija Arsic (1776-1843) was introduced to the Serbian national pantheon as the first Serbian woman writer and philosopher of the modern age. This image was based first and foremost on her book "Useful Thoughts on the Four Seasons" which appeared in Budim in 1816 under that author's name. In the second half of the twentieth century several scholarly studies and a biography were devoted to Arsić. More recently this image has attracted the attention of scholars of women's literature in South Slavic countries. These scholars note that her "Thoughts", while influenced by Western pre-romantic (sentimentalist) literature, illuminate a wide range of fields, including philosophy, ethics, history, natural science, anatomy, physics, and religion, while at the same time they introduce the genre of the "feminist essay" into Serbian literature. The poems that are included in "Thoughts" appear in anthologies of Serbian literature as original poems by Arsić. 
The present essay shows that the ideas about the originality, European erudition, cosmopolitanism, personal tone, philosophical gifts and poetic talent are highly exaggerated, and that the image of this author is a cultural construct that was created at a certain stage of the formation of Serbian national literature and was reconceived at a later time. The essay establishes that Arsićs "Useful Thoughts" is a compilation of essays, tracts, and poetry that appeared in Russian journals from the late 1780s to the early 1810s. These works (including some by Nikolai Karamzin) were transferred into her book with minor orthographic and grammatical changes (e.g. masculine noun endings are changed to feminine ones) and without any indication of the source. The work of the compiler of "Thoughts" consisted solely in taking the sentimental texts of Russian male authors and attributing them to a pious female author. The essay does not simply give the direct sources of this "Slavono-Russian" book of "the first Serbian woman writer" and describe the process of adaptation of the "foreign" as a stage of the national and literary self-affirmation of the "younger" Slavic culture, but it also offers material for a more general (philological and literary-critical) study of the "Slavono-Russian" period in the history of Serbian literature in particular and "pan-Slavic" pre-romanticism more generally. The case of Arsić is likewise interesting for a comparative analysis of the formation of national literary "pantheons" and for a gender history of Russian and other Slavic literatures.

\section{Keywords}

Eustahija Arsić, Serbian Literature, Russian Sentimentalism, Nikolai Karamzin, Translation studies, nationalism, woman's writing, "feminisation", mystification 
Любезне мое друге и сестре! купуйте книжице, пренумерирайтесе, уписуйте имена дражайша ваша, да се споминпмо, доклесмо живе здп въ краткомъ времени жизни; а и када се къ Богу преселимо, наћиће у књигама имена наша потомиы наши, $u$ споминятье, и видић дае и садешнпга века нашегъ пола читателница было ${ }^{1}$.

Евстахия Арсич

\section{Довольно вы играли мной, Теперь другими вы играйте, Меня пустите на покой.}

Анонимный перевод стихов из «Жиль Блаза» А.-Р. Лесажа

\section{1. Портрет на чашке}

В истории сербской литературы Евстахия Арсич [Еустахија Арсић, 1776-1843] известна как просветительница, последовательница Досифея Обрадовича, хозяйка одного из ранних сербских литературных салонов, поборница сербского женского образования в Австрии, меценатка и, наконец, первая со времен средневековой монахини Евфимии сербская писательница и даже протофеминистка, вполне оправдавшая «поређење [сравнение. - И. В.] са Жорж Санд» [Косh 2007: 161; Јовићевић 2014; Лош 2014]³.

1 «Любезные мои друзья и сестры! Купите книжицу, подпишитесь на нее, впишите туда дражайшие имена ваши, чтобы мы помнили их, пока мы еще здесь живы в краткое время сей жизни; а когда переселимся к Богу, наши потомки найдут в книгах наши имена, и вспомнят, и увидят, что и в нынешнем веке были читатели нашего (женского) пола» [Арсичь 1816: 14].

2 Цит. по: [Гуковский 1933: 382].

3 См. библиографию Арсич на посвященной ей странице на сайте «Књиженство, теорија и историја женске књижевности на српском језику до 1915. године» (дата обращения: 01.06.2019), подготовленной Белградским университетом: http://knjizenstvo.etf.bg.ac.rs/sr/authors/eustahija-arsic. Здесь же дана краткая биографическая справка об Арсич: «Прва српска списатељица после Јефимије и прва жена из Србије која је штампала своја књижевна дела. Рођена је у породици Цинцић у Иригу, 14. марта 1776, а умрла у Араду 17. фебруара 1843. године. О њеном школовању нема много података, али се зна да је била образована. Читала је Рајића, Доситеја, Стојковића, Кенгелца и Јулинца. Тек после удаје за племића Саву Арсића, дугогодишњег сенатора и градског начелника арадског почиње да се бави књижевним радом». 
Репутация Арсич зиждется на двух книгах, написанных на так называемом славяно-сербском языке, использовавшемся сербской образованной элитой в Габсбургской империи до реформы литературного языка Вука Караджича ${ }^{4}$, и напечатанных гражданским шрифтом, - (1) короткой брошюре «Совђтъ матерній предрагой обоего пола юности сербской и валахійской» $(1814)^{5}$, включавшей программное обращение к «дражайшим читателям и читательницам рода моего» о пользе чтения ${ }^{6}$ и несколько хвалебных и утешительных стихотворений-песен, написанных от лица просвещенной женщины, и (2) 160-страничном томе дидактических философских, научных и поэтических текстов «Полезная размышленія о четырехъ годишнихъ временехъ» (1816), поднесенном от ее имени в дар Сомборским православным подготовительным училищам «на просвјешченије јуности» [Гавриловић 1970: 364-365].

«Первой писательницей сербской» Арсич назвал поэт Григорий Якшич в «Песне», посвященной ей и ее мужу Савве Арсичу - «тридесятьлетнему Гражданачалнику Старо-арадскому, и Предуготовническихъ Училищъ Валахійскихъ многозаслуженному мъстному Директору» [Якшичъ 1815] 7 . В периодизации сербской литературы, предложенной Лазарем Боичем в том же 1815 г., имя Арсич значится первым в алфавитном списке представителей нового периода сербской литературы [Боичъ 1815: 25]. «Првой у народу свому писательки» посвятил в 1820 году Павле Берич свой перевод «Агатона» Виланда [Берић 1820]. В «Сербске льтописи» за 1827 г. Георгий Магарашевич отмечал, что Арсич «у српској литератури перва од свога нежнога пола изданијем различни по већој части поетически дјела вниманије и почитаније себи добила» ${ }^{8}$. В 1833 г. писатель и переводчик Иоаким Вуич посвятил ей в благодарность за покровительство свое «Животоописание» и коротко

4 В периодизации сербского литературного языка, предложенной Б. Унбегауном, язык Арсич характерен для третьего, предреформенного, этапа, охватывающего 1780 -е - 1800-е гг.: это язык «“славяно-сербский”, близкий к русскому высокому “штилю” [Толстой 1988: 100]. О «русской струе» и использовании русского языка в сербской литературе XVIII в. см.: [Скерлић 1909: 194-221; Гудков 1977].

5 Эта маленькая книжка была посвящена женой арадского бургомистра Арсич просветителю Урошу Несторовичу - надзирателю народных «восточнаго несоединенаго Исповедания Училищ», в том числе и предуготовительного Староарадского. Арад - город в современной Румынии - стал в начале XIX в. одним из центров славяно-сербского просвещения [Панић 2015: 67-69].

6 «Яко женскій полъ есть цвьтение на земли у вертограду Божію» [Арсичь 1814: 25].

7 Стихотворение было написано по радостному случаю произведения супругов в степень благородства «въ спомен щедро излиянныхъ Ими на отчественныя Музы милостей», случившегося 5-го декабря 1814 г., и подписано инициалами Г. Я[кшичъ ].

8 «Летопис Матице српске» (1827), књ. 10, 18. 
рассказал о печально сложившейся супружеской жизни своей благодетельницы [Вуичь 1833: 97-98]. Потом о ней на полвека забыли.

В конце XIX в. романтический образ Арсич как первой сербской писательницы нового времени был введен в национальный литературный пантеон Ильей Огняновичем и Данилой Живалевичем в статьях, опубликованных в журнале «Явор» [Огњановић 1891; Живаљевић 1891] В этих и некоторых других работах была предпринята попытка реконструкции биографии Арсич, где подчеркивались мотивы несчастной судьбы писательницы, ее скорби по третьему мужу, объяснявшей, по мнению биографов, ее отказ от литературной деятельности, и ее легендарной красоте [Петровић 1959: 63]. Во второй половине XX в. жизни и творчеству Арсич были посвящены несколько научных статей. В 2001 г. вышла ее «итоговая» биография, написанная Владимиром Миланковым. В последние годы этот образ привлек к себе внимание исследователей женской литературы в южно-славянских странах и был растиражирован во множестве газетных и сетевых публикаций национально-патриотического характера.

Показательно, что заметное оживление общественного интереса к полулегендарной фигуре Арсич совпало с «чудесным» обнаружением ее портрета на фарфоровой чашке, случайно найденной одним из потомков ее первого мужа. Сообщивший об этом открытии автор (Ладислав Варга [Варга 2001]) даже представил себе картину, как юная красавица в своем роскошном салоне пьет чай из этой чашки работы известного австрийского мастера Бауэра, не предполагая, сколь ценным для потомков окажется ее образ два века спустя ${ }^{10}$. С тех пор этот портрет постоянно поме-

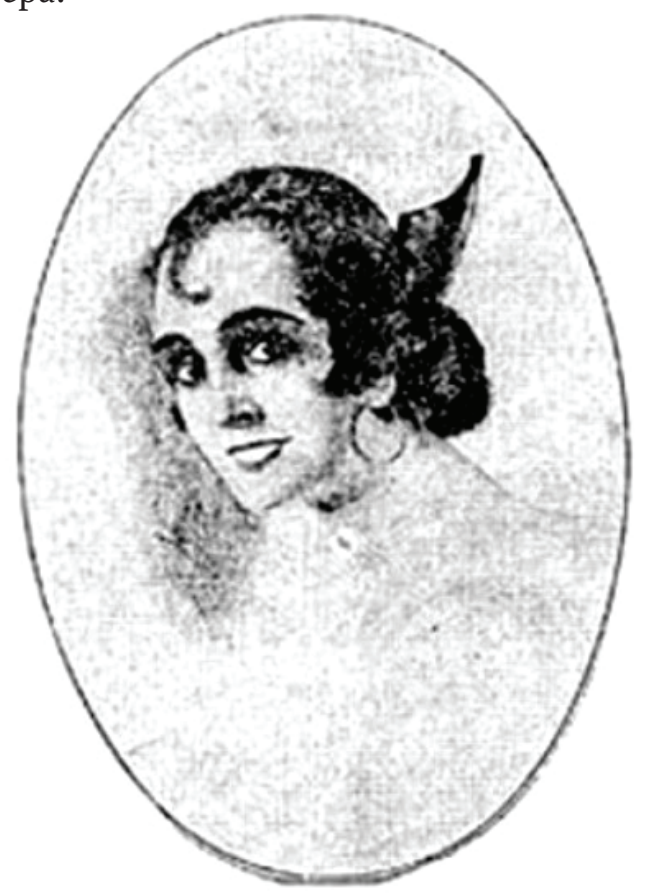

9 Любопытно, что в номерах «Явора» за тот же год печаталась драматическая поэма о первой женщине-поэте Сафо.

10 См. статью об Арсич в сербской Википедии: https://sr.wikipedia.org/wiki/ Евстахија_Арсић (дата обращения: 01.06.2019). 
щают в антологии и словари сербских писателей. Есть он, разумеется, и в сербской статье об Арсич в Wikipedia и ее английской версии. С публикацией этого сомнительного портрета мифологизация образа первой сербской писательницы получает свое логическое завершение.

Наиболее развернутую характеристику творчеству Арсич дает английская исследовательница и переводчица Селия Хоксворт (Celia Hawkesworth) в книге, посвященной сербским и боснийским писательницам:

Вся ее деятельность как умудренной жизненным опытом женщины была вызвана желанием быть полезной и поучать современников с помощью своих практических советов в различных областях жизни и философских размышлений, которые она считала одинаково важными. Ее сочинения вдумчивы, красноречивы, серьезны и ясны. Они свидетельстивуют о ее впечатлительном уме и глубокой преданности своему делу в эпоху, когда участие сербской женщины в какой-либо литературной деятельности было почти неслыханным. Исследователь XX века Милан Богданович указывает на то, что интонация ее сочинений отличается от сочинений мужчин-современников и выдает специфически женское начало ${ }^{11}$ [Hawkesworth 2000: 93; здесь и далее перевод мой. - И. В.].

В настоящей статье речь пойдет о второй, гораздо более амбициозной, нежели «Совђт матерний» ${ }^{12}$, книге Арсич, вышедшей в Будиме в 1816 г. с указанием имени сочинительницы. Ее полное название - «Полезная размышленія о четырехъ годишнихъ временехъ, съ особеннымъ прибавленіемъ о Трудолюбіи человька, и оттуду происходящей всеобщей ползь, сочиненна и на свњтъ издана Еустахіею отъ Арсичъ» [курсив мой. - И. В.].

\section{2. Очаровательная энциклопедическая личность}

В 1891 г. «Полезным размышлениям» Арсич посвятил библиографическую заметку Д. Живалевич, отметивший европейскую образованность ее сочинительницы, знакомой со многими научными вопросами [Живаљевић 1891: 141]. Исследователи творчества Арсич указывают, что ее «Размышления» написаны под влиянием западной предромантической (сентиментальной) литературы, освещают широкую проблематику на границе философии, этики, истории, естественных наук, анатомии, физики и религии и вводят в сербскую литературу жанр

11 [B] etrays a specifically feminine quality».

12 В целом эта книжка вписывается в ряд родительских наставлений юношеству, популярных как в церковно-славянской школьной традиции, так и в секулярной просвещенческой (ср. советы матерей и воспитательниц де Бомон, Жанлис и т. д.). О риторических особенностях и идеологии этой книги см.: [Јовићевић 2014]. 
феминистического эссе («феминистеског есеја») [Косh 2007: 28; Кох 2007: 161]. Автора «Размышлений» называют талантливой писательницей и поэтессой, подражавшей немецким, французским и английским сентименталистам. Одна из первых исследовательниц ее творчества предположила, что Арсич была еще и талантливой переводчицей, включившей в «Полезные размышления» свое вольное переложение «Времен года» Дж. Томсона, сделанное с «какого-то немецкого перевода» [Петровић 1959: 68]. Стихотворения, вошедшие в «Размышления», печатаются в антологиях сербской литературы как оригинальные [Лесковац 1953; Милослављевић 2004; Радовановић 1981]. В 2013 г., то есть почти через двести лет после первой публикации, тщанием общества румынских сербов книга Арсич была перепечатана в Темишоаре с предисловием, примечаниями и приложением известного нам портрета писательницы [Арсић 2013].

В своей книге С. Хоксворт дает подробный обзор содержания «Полезных размышлений», который мы приведем полностью как отправную точку для наших собственных наблюдений и размышлений:

Предисловие предупреждает читателя об опасности оказаться во власти мнимостей и иллюзий и использует метафору театра для того, чтобы показать, как привлекателен, но обманчив и зачастую губителен для человека материальный мир. Автор призывает читателя изучать этот мир с осторожностью и полагаться на собственный разум и силу критического суждения, которые позволяют ясно видеть правду за обманчивой наружностью.

За предисловием следует гимн божественной славе, превосходящей все земные виды славы и подчеркивающей подчиненность человеческого разума, воспеваемого в книге, высшей власти Создателя.

В состав книги входят два длинных раздела-сочинения и многочисленные короткие статьи-фрагменты. Первое из длинных сочинений посвящено теме четырех возрастов человека - детству, юности, зрелости и старости $[\ldots]$. В жизни любого человека есть время для беззаботного веселья, время для избавления от иллюзий, время для размышления и для того, чтобы поделиться с другими мудростью, накопленной в результате полезной и добродетельно прожитой жизни.

Второе длинное сочинение состоит из стихотворений на каждое время года, за которыми следуют аллегорические рассуждения в прозе, опять же посвященные четырем фазам человеческой жизни. Часть этих отрывков выражают, несмотря на некоторую неловкость языка изложения, достаточно сложные философские мысли.

Короткие фрагменты охватывают самый широкий круг вопросов: полезность философии для человеческого рода; простор для деятельности человека в обществе; любовь к Богу, отличающая человека от животного; 
значение трудолюбия; важность воспитания в себе таких положительных чувствований, как умение довольствоваться малым и не становиться рабом страстей; представление о человеке как, в первую очередь, биологическом существе; воспитание разума путем учения, приближающего читателей к достижениям великих европейских народов; благотворное влияние природы; необходимость культивирования хорошей крови ${ }^{13}-$ интригующая смесь научного языка с философией и этикой; приуготовление себя к смерти без страха; тайная связь между всеми сторонами сложной человеческой личности; место человека между землей и небом и Театр жизни; образование как путь, помогающий людям сообща приблизить более просвещенное будущее, в прямом соответствии с волей Господа.

Книга завершается несколькими медитативными стихотворениями в форме молитв и гимнов, в которых автор обращается к мысли о смерти и прямому общению с Богом в безмолвии ночи, и все сочинение заключается последней прощальной молитвой [Hawkesworth 2000: 95-96; курсив мой. И. В.].

Из этого детального обзора Хоксворт выводит образ замечательной сербской женщины периода национального возрождения:

Эта книга открывает нам замечательную личность, мудрую, рассудительную, хорошо начитанную, с огромной жаждой знаний и непреодолимым желанием поделиться этой стастью с соотечественниками. Тематический диапазон этой книги неизбежно условен в контексте идей Просвещения, которые она продвигает и, таким образом, является в известной степени анахроничным для времени появления книги. Между тем, в авторском контексте эта книга представляет собой яркий и убедительный документ, предлагавший своим читателям значительное разнообразие тем для ознакомления и размышления. Книга также впечатляет многообразием представленных в ней стилей и жанров: Арсич уверенно себя чувствует как в простом стихотворении, славящем природу, так и в мистическом гимне Богу и сложном рассуждении о биологии человека и морали [Hawkesworth 2000: 96; курсив мой. - И. В.].

Еще дальше в своей апологии Арсич идет польская исследовательница Магдалена Кох. По ее мнению, случай Евстахии Арсич представляет собой особый литературный феномен, выражающий страстное стремление славянской женщины к знанию и способность говорить и писать о нем на своем собственном, индивидуальном языке [Koch 2007: 32-33].

В самом деле, Арсич, владевшая, как указывают ее биографы, несколькими европейскими языками (в частности, немецким, английским, румынским, латинским, греческим и французским), следовала

$13 \ll[T]$ he need to cultivate good blood». 
в своем сочинении сентиментально-просветительской традиции второй половины XVIII в., и ее книга полезных размышлений была одной из первых философско-дидактических книг на славяно-сербском языке.

Но была ли она автором этого дидактико-метафизическо-лирического сочинения? В предлагаемой статьемы покажем, что представления об оригинальности, европейской образованности, космополитизме, личном тоне, философском даре и поэтическом таланте Евстахии Арсич сильно преувеличены и что ее авторский образ, как мы полагаем, является культурным конструктом, созданным на определенном этапе формирования сербской национальной литературы и востребованным и переосмысленным в более позднее время.

Здесь необходимо оговориться. Мы не ставим под сомнение сложившееся представление об Арсич как хронологически первой сербской писательнице нового времени. Наша задача - историоризировать литературный образ сочинительницы «Полезных размышлений», декларированный на титульном листе ее книги. Иначе говоря, нас интересует, из чего (раздел 3), как (4-5), в каких условиях (6) и с какой иельью (7-8) сделано главное сочинение Евстахии Арсич из Арада.

\section{3. Материал и традиция}

Начнем с того, что непосредственное влияние на Арсич оказала не немецкая (английская или французская), но русская литература XVIII в., с которой немногочисленная сербская образованная элита XVIII - начала XIX в. была хорошо знакома [Скерлић 1909: 208-211]. Более того, как нам удалось установить, «Полезные размышления» Арсич (за исключением очень небольшого числа вставок, написанных на славяно-сербском языке, отличном от сербско-русского или даже чисто русского языка помещенных в этой книге текстов) являются компиляцией статей, трактатов и стихотворений, опубликованных в российских журналах и сборниках конца 1780-х - начала 1810-х гг. (большей частью без указания имен переводчиков, но с более или менее детальными указаниями на иностранное происхождение их текстов). Эти произведения были перенесены в книгу целиком или в сокращении и подвергнуты минимальному редактированию ${ }^{14}$ :

14 Заметим, что шрифт «Полезных размышлений» Арсич идентичен шрифту, использовавшемуся в журнальных изданиях московской университетской типографии «Приятное и полезное препровождение времени», «Иппокрена» и др. [Шицгал 1974: 69]. 


\section{Содержание «Размышлений»}

Предсловіе (Благоразумни читатели!)

Слава (1-4)

Четыри Возраста человека.

I. Младенецъ. II. Юноша.

III. Мужъ. IV. Старецъ (5-18)

Філософіа (18-20)

Человекъ в общеніи живота (20-22)

Четыри времена годишня. Весна (23-35), Лето (36-53), Есень (54-70), Зима (71-81)

О трудолюбію (82-89)

(Человекъ одареный разумомъ, упражняющійся въ науках и художествахъ) (90-92)

\section{Источники}

Источник не установлен (какое-то церковно-славянское поучение, опубликованное в России в середине XVIII в.?).

Н. Д. Иванчин-Писарев. Истинная слава // Вестник Европы. 1814. Т. 75. С. 60-67

[И. Вердмюллер?]. Четыре возраста человеческие // Приятное и полезное препровождение времени. 1796. Ч.10. № 79. С. 401-410

Отрывки из философии [Вейсса] // Пантеон славных российских мужей. 1816. Ч. 1. С. 63-64 (перевод 1807 года?)

[Н. М. Карамзин]. Человек в общении с Богом через религию. Из «Статей из Contemplation de la nature, Боннетова сочинения» // Детское чтение для сердца и разума. 1789. Т. 2. Ч. 19. 165-205

[Н. М. Карамзин]. Весна, Лето, Осень, Зима [прозаическое переложение «Тhe Seasons» Дж. Томсона] // Детское чтение для сердца и разума. 1787. Ч. 9. С. 195-205. Ч. 10. С. 193-207. Ч. 11. С. 193-207. Ч. 12. С. 193-206.

[Н. М. Карамзин]. О Досуге. Сочинение Философа Гарве // Московский журнал. 1792. Ч. 6. 167-176.

[Н. М. Карамзин]. Человек, одаренный разумом, упражняющийся в науках и художествах. Из «Статей из Contemplation de la nature, Боннетова сочинения» // Детское чтение для сердца и разума. 1789. Т. 2. Ч. 19. С. 165-205.

15 В настоящей статье мы ограничимся лишь выявлением русских источников «сочинений» Арсич. Подробное сличение последних с русскими переводами и их оригиналами выходит за пределы поставленной нами в этой работе задачи. 
О удоволствіи (92-97)

(Человекъ разсматриваемый како существо телесно). Человекъ (98-100)

О Природе Человека (100-107)

Просвещеніе Націи и

человеческаго рода (108-117)

Изъ согледанія Природы:

1. Невидимое кругообращеніе.

2. Приуготовленіе сока нервъ.

3. Смерть. 4. О молчаніи природы.

5. О увереніи всехъ народовъ о будущемъ. 6. Изъ жизни человека. 7. О определеніи человека посмерти. 8. О будущихъ откровеніяхъ. 9. Заключеніе (118-145)

Молитва отходя ко сну (145-146)

Нощныя размышленія (146-145)

Гробъ (154-156)
[Н. М. Карамзин]. Годвин У. Нравственные опыты. Английского доктора Годвина. І. Об удовольствиях // Пантеон иностранной словесности. 1798. Кн. 3. С. 54-61.

[Н. М. Карамзин]. Человек, рассматриваемый как существо телесное. Из «Статей из Contemplation de la nature, Боннетова сочинения» // Детское чтение для сердца и разума. 1789. Т. 2. Ч. 19. С. $165-205$.

[Н. М. Карамзин]. Homo Duplex: Внутренний человек двойствен. Бюффон // Пантеон иностранной словесности. 1798. Кн. 2. С. 54-69.

Просвещение наций и человеческого рода // Иппокрена, или Утехи любословия. 1799. Ч. 3. С. 33-40.

[Феофилакт Покровский]. Философические отрывки из созерцания природы // Иппокрена, или Утехи любословия. 1799 год. Ч. 1. С. 97-120, 145-150.

Митрополит Платон. Молитва отходя ко сну // Поучительные слова при Высочайшем Дворе. С.-Петербург, 1780. C. 229.

Нощныя размышления // Картина бытия помышлением созерцаемая, или умственное воззрение на драгоценность жизни. Перевод с Англинскаго языка. Москва, 1798. С. 12-21.

[Н. М. Карамзин], «Кладбище» [впервые опубл. в «Московском журнале» за 1792 г. под названием «Могила». Ч. 7. Кн. 2. С. 109-111]. 
Слово надъ гробное («Надежда и щастие сад мне опрощайте...») (156)

Тестаментъ (157-159)
[В. Теплов]. «Надежда, щастие, прощайте» [перевод дистиха из Греческой антологии (Ап1. Рa1. 9.49). Завершающие строки кн. 3 «Жиль Блаза» А.-Р. Лесажа (см. также четверостишие В. Подшивалова: [Добрицын 2008: 417])

Иоанн Златоуст. Из 3-й и 4-й бесед // Святаго отца нашего Иоанна Златоустаго архиепископа Константинопольскаго беседы на первую моисеову книгу Бытия переведенныя с Греческаго на Российский язык. Ч. I-II. С.-Петербург, 1766

\section{В качестве иллюстрации приведем четыре (любимое число Арсич) взятых наугад фрагмента из ее книги и сравним их с русскими текстами- источниками:}

\begin{abstract}
1. Составъ, изъ коего вся отдъленія въ ть⿻丷木 есть кровь. Изъ нЊе отдъъляется, желчь, слына, съьменная житкость и сокъ нервъ, весма достойны примъъчанія особито тыя премъны, кои происходе съ посль'ьнимъ въ разныхъ періодахъ жизни [Арсичь 1816: 121-122].
\end{abstract}

2. Милый и кротчайшій! коликія примамляемые красоты его! онъ подобенъ Ангелу, сама любовь небесная всемогущею десницею образовала его. Чело его прекрасно као Май, чистая непорочная душа сіяетъ въ голубинъъ очію его. На лилейныхъ образахъ распускаются пупки ружицы, играетъ нъжная брадица его; радость⿱⿻丷木女 разливается во тонкихъ жилахъ его; на руменыхъ устахъ покоятся прелестныя Граціи [Арсичь 1816: 5].
1. Составъ, изъ котораго всъ

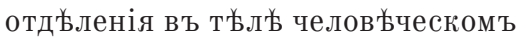
происходятъ, есть кровь: Изъ нее отдъляется желчь, слюна, съменная жидкость и сокъ нервъ. Весьма достойны примъччанія особливо тъв перемъны, которыя происходятъ съ посльъднимъ въ разныхъ періодахъ жизни [Иппокрена 1799: 102].

2. Милая крошечка, ах! сколь непринужденны красоты его! он подобенъ Ангелу. Сама любовь небесная всемогущею десницею своею образовала его. Чело его прекрасно, какъ Май. Чистая непорочная душа сіяетъ уже в голубыхъ глазенкахъ его; на лилейныхъ щечкахъ распускаются алыя розы, и играетъ нъжжная улыбка; радость разливается въ васильковыхъ жилкахъ его; на алыхъ устахъ его покаятся прелестныя Граціи [Приятное и полезное... 1796: 401]. 
3. Безмолвіе, мрачность, величественная чета, о Вы, коихъ присутствіе укръпляетъ душу, и коихъ невидимая сила возставляетъ падшаго уныніе человъка, и утверждает его на собственномъ разумь!! способствуйте мнъ! [Арсичь 1816: 147].

4. Често жаркій югъ собираетъ силную непогоду и погубляетъ дъљланія цъллаго года, сначала едва движутся верьхови древесъ и тихій шумъ чуесе среди колебающихся нива, когда вътаръ усилится, тогда вся атмосфера приходитъ въ волнованіе и ужаснымъ рвеніемъ весь міръ трепетати станетъ, тогда главе древесъ приклоняются до самаго корена ихъ, и покрываютъ землю зеленымъ листьемь
3. Безмолвіе, мрачность, величественная чета, о вы! коихъ присутствіе укръпляетъ мою душу, и коихъ невидимая сила возставляеть падшаго въ уныніе человъка, и утверждаетъ его на собственномъ разумъ, способствуйте мнъ! [Картина бытия 1789: 12].

4. Часто жаркой Югъ собираетъ сильную непогоду и погубляетъ работы Года. Сначала едва движутся верьхи деревъ, и тихой шумъ слышенъ среди колеблющихся нивъ. Когда же вътръ усиливается; когда вся атмосфера приходить в в волненіе и ужаснымъ ревомъ весь міръ трепетать заставляетъ: тогда глава льсовъ преклоняется до самаго корня ихъ, и покрываеть землю незрьлыми листьями [Карамзин 1787a: 198].

Совершенно ясно, что перед нами не оригинальное произведение, a de facto сборник (или антология) «красот» русского нравоучительного сентиментализма (в основном московских журналов конца 1780-х 1790-х гг.), составленный и «несколько осербленный» (выражение Н. И. Толстого [Толстой 1988: 216]) и архаизированный его благочестивой ценительницей. Принципом отбора заимствованных текстов, насколько мы можем судить, является их отношение к заглавной теме книги - размышления о четырех временах года и степенях жизни. Очевидна генетическая связь этого сборника не только с обычными для века Просвещения собраниями поучений, занимательных сведений, переводных «магазинов» (3. Орфелин, П. Стойшич) и «физико-теологических» размышлений, но и со старинной славянской традицией «вертоградов», церковношкольных сборников и тематических коллекций душеполезных размышлений, - традицией, «не исчезнувшей даже в XVIII веке на юге славянства и на Руси в среднем и нижнем течениях “века просвещения” " [Сперанский 1904: 566; Idem 1963: 101-102].

Конечно, уже сами по себе выбор и объединение заимствованных из чужой литературы текстов в одну книгу могут быть интерпретированы как творческий акт составителя, но удивляют масштаб этих практически дословных, «одноязычных», заимствований и лингвистическая неоднородность - вплоть до какофонии - книги в целом: церковно- 
славяно-сербское вступление сменяется чуть осербленным русским книжным языком XVIII в., в состав некоторых русских текстов введены сербские (диалектные) интерполяции, замена отдельных русских слов, букв и грамматических форм на сербские проводится крайне непоследовательно. Добавим также, что в книге отсутствует какой-либо план, нет оглавления, стихотворные тексты написаны в разных версификационных системах, есть большое число опечаток и незаконченные предложения. Создается ощущение, что «Полезные размышления» - в отличие от другого сочинения Арсич, «Совђт матерний», - написаны на двух (или даже трех, если считать церковно-славянские вставки из Псалтири) языках и на скорую руку, и это торопливое «смешенье» трудно объяснить исключительно диглоссией сербской элиты и неустоявшимся (еще не состоявшимся) сербским литературным языком и еще не кодифицированной грамматикой того времени [Hawkesworth 2000: 96].

Единственное, что соединяет части этой книги, помимо общей (и то не для всех текстов) темы, - это указание на то, что все они «сочинены и на свет изданы» госпожою Евстахиею Арсич в венгерском Будиме в 1816 г.

Разумеется, заимствование сербским автором начала XIX в. русских литературных произведений является вполне рядовым явлением. Исследователь русско-сербских литературных связей П. А. Кулаковский писал, что

русская рукопись или печатная книга в общем сознании была также и сербскою, понятною и, так сказать, своею для тогдашнего просвещенного серба, а если при переписке или перепечатке производились в таком русском произведении некоторыя перемены в выражении, то оне были ничтожны и часто крайне непоследовательны.

Более того, «в общем сознании сербов готово было укрепиться убеждение, что язык русской письменности XVII и даже XVIII века есть именно тот литературный язык, которым должна пользоваться сербская письменность» [Кулаковский 1903: 1-2] ${ }^{16}$. Исследователи указывают, что в основе «сербской эксплицитной и имплицитной поэтики перевода XVIII в.», наиболее ярко представленной в творчестве Досифея, была классицистическая и просветительская «концепция перевода-адаптации» [Сибинович 1989: 36-37] ${ }^{17}$. В то же время историкам

16 Личные библиотеки образованных сербов вплоть до конца 1810-х гг. включали в основном церковно-славянские и русские книги. Русские священники постоянно приглашались сербскими дворянами и богатыми купцами в качестве учителей [Заболотский 1908; Скерлич 1909: 208-211]).

17 Первым сербским переводом из русской поэзии XVIII в. М. Сибинович называет перевод Дошеновича «Разговора с Анакреоном», автор которого, по мнению 
литературы известны почти дословные «переводы» на славяно-сербский произведений русских поэтов XVIII в., причем без указания на авторство или с присвоением себе оного (ср. подобные «переводы» од Державина [Францев 1924: 60-61; Заболотский 1908: 282-283; Сибинович 1989: 37] $)^{18}$. Известны сербской образованной элите были и произведения Карамзина (правда, до сих пор считалось, что первые переводы из его сочинений появились на сербском языке значительно позже [Вулетич 1976: 113-115]).

И все же случай Арсич, до сих пор не замеченный в литературе о сербско-русских литературных связях, представляется нам заслуживающим особого внимания. Речь, повторим, идет о 160-страничной книге, целиком составленной из почти не обработанных русских переводов европейских авторов XVIII в. ${ }^{19}$

Где могла познакомится жена арадского бургомистра с этими текстами? Московские сентиментальные журналы и альманахи, разумеется, могли находиться в личной библиотеке четы Арсич или в арадском школьном книгохранилище (имя Арсич часто встречается в списках субскрибентов первой трети XIX в. [Петрович 1959: 64-65]) ${ }^{20}$. Русские книги и журналы можно было купить в новосадской книжной лавке, найти в библиотеке королевского Пештского университета или в книжных собраниях просвещенных сербов, тяготевших к русской культу$\mathrm{pe}^{21}$. Вполне вероятно, что помощь в создании и публикации сборника

исследователя, стремится отойти от русского текста и изменяет смысл оригинала [Сибинович 1989: 30-31].

18 Сибинович утверждает, что переведенная и «присвоенная» Стаматовичем ода «На смерть князя Мещерского» (у сербского автора - «Плач на смерть преосвещенейшего Г. Иосифа Путиника, епископа темишварского и пр.») является не плагиатом, но поэтической переработкой, обусловленной стремлением переводчика «передать сербскому читателю с помощью церковнославянизмов высокий стиль произведения, выражающего печаль в связи с кончиной высокопоставленного лица» [Сибинович 1989: 37] и создать «новое, свое произведение» [Сибинович 1989: 38]. Такие переводы, по мнению исследователя, следует рассматривать в контексте острой «дискуссии вокруг славяно-сербского и русско-славянского литературных языков» [Сибинович 1989: 31-32].

19 Заметим, что сербский просветитель Йован Раич в своем собрании «избранных историй» «Цветник» (Будим, 1802) указывал, что это перевод немецкой книги Accela philologica. Составитель близкого книге Арсич по жанру сборника «Должности человька» Петр Стойшич также указывал в заглавии, что его написанная на славяно-сербском языке книга «изъ разныхъ иностранныхъ изданій» собрана «и во едино тьло» составлена (Будим, 1816). «Смешенье языков» в книге Арсич выделяет ее на фоне других книг того времени, написанных на славяно-сербском языке, включая ее собственную книгу «Совђт матерний».

20 Теоретически можно допустить, что в ее распоряжении уже был какой-то готовый рукописный сборник (прототекст), привезенный из России или составленный в Сербии.

21 Между тем следует отметить, что указанных выше журналов нет в «Каталоге разних церковних, молитвених, исторических и школских сербских и славенских 
Евстахии Арсич мог оказать кто-то из покровительствуемых ею и ее мужем знатоков и почитателей русской словесности, вроде упоминавшегося выше Г. Якшича, жившего в царствование Павла I в России и писавшего стихи как по славяно-сербски, так и по-русски ${ }^{22}$, или переводчика Павла Берича, впоследствии посвятившего Арсич свой перевод виландовского «Агатона» ${ }^{23}$. (Разноязычность и хаотичность сборника вполне может объясняться участием в его создании нескольких сотрудников-переписчиков.) Как бы то ни было, работа составителя «Размышлений» в целом свелась к тому, чтобы «христианизировать», «авторизовать», «национализировать» и «феминизировать» переведенные российскими авторами-мужчинами сентиментальные тексты.

\section{4. Обароченный сентиментализм}

Начнем с того, что Арсич последовательно архаизирует (славянизирует) язык русского сентиментализма и стремится избежать крайностей его идеологии в соответствии с религиозно-нравоучительной традицией, влиятельной в сербской литературе XVIII в. Можно сказать, что она переводит русскую сентиментальную прозу и поэзию назад, в досекулярную или полусекулярную барочную традицию24. В этом смысле заглавие и композиционный принцип книги Арсич (времена жизни-года) свидетельствуют не столько о непосредственном влиянии на нее просветительского сентиментализма, сколько о восприятии ею русской сентиментальной топики сквозь призму старой религиозно-аллегорической традиции изображения четырех «степеней» природы и жизни (о ее сербском изводе см.: [Thomson 2000: 262-263]) $)^{25}$. С. И. Николаев любезно указал нам в этой связи на славянскую параллель к творчеству Арсич - барочные сочинения «первой» польской поэтессы XVIII в. Эльжбеты Дружбацкой (Elżbieta Drużbacka, ок. 1695-1765),

книг, которија находјатсја у г. Дамјана Каулициј книгопродавца в Новом Саде» (Будим, 1804).

22 Известно, что Якшич изучал философию в Пеште и был хорошо знаком с просветительскими идеями. Состоял на русской военной службе и в 1801 г. получил от Павла I мальтийский орден. Хорошо знал русскую литературу конца XVIII в. В 1817 г. вернулся в Россию, где опубликовал несколько своих сочинений [Достян 1989: 16-23].

${ }^{23}$ Немецкий путешественник по сербским землям О. фон Пирх приписал этот перевод Арсич (равно как и переводы «Задига» Вольтера и «Времен года» Томсона) [Pirch 1830: 166-169].

24 Обращение Арсич с «чужими» текстами ближе переводческой практике Симеона Полоцкого [Николаев 2004: 11-19], нежели переводам-переложениям Карамзина.

25 Барочный характер носит и Предисловие к книге Арсич, в котором «широкий свет» сравнивается с театральным позорищем. О сербской барочной традиции см.: [Павић 1970]. 
выпустившей в 1752 г. свой единственный сборник «духовных, панегирических, моральных и светских стихотворений», включавший «Opisanie czterech części roku» (сборник был издан тщанием ее друга и патрона, назвавшем ее в предисловии «польской Сапфо» и «Сарматской музой») [Hawkesworth 2001: 18].

Приведем наиболее яркий, с нашей точки зрения, пример идеологической архаизации Арсич заимствованных источников (причем при их почти дословном цитировании в тексте книги!). В состав «Размышлений», как указано в названии книги, Арсич включила «особенное прибавление» «О Трудолюбии человека, и оттуда происходящей всеобщей пользе». Как мы установили, источник этого текста - карамзинский перевод из Гарве, датируемый 1792 г. и потом перепечатанный во всех изданиях «Пантеона иностранной словесности». Но в этот текст, заимствованный Арсич почти дословно, включены несколько принципиальных (если не сказать полемических) изменений.

Прежде всего, Арсич меняет слово «досуг» на слово «трудолюбие» в заглавии и во всем тексте фрагмента и таким образом переводит важную для карамзинского сентиментализма апологию вольному состоянию человека (условие «спокойной деятельности») в традиционное для жанра религиозно-педагогических поучений прославление трудолюбия как христианской добродетели:

\section{Карамзин, «О досуге, сочинение философа Гарве. Досугъ есть ничто святое»}

Подъ досугомъ разумью я то состояніе человъка, въ которомъ ему свободно заниматься тъмъ, что для него пріятнъе ... Досугу противны два рода жизни: жизнь дъъловаго человъка и разсъянная жизнь [Карамзин 1792а: 167].

Кто можеть говорить о досугъ, не упомянувъ о сельской жизни и наукахъ? Нигдъ досугъ такъ не пріятенъ, какъ въ деревнъ; никакимъ предметомъ не можеть онъ быть столь хорошо занять, какъ науками [Карамзин 1792а: 172].

\section{Арсич, «О трудолюбію»}

Подъ трудолюбіемъ я разумъвамъ то состояніе человъка, въ коемъ ему свободно предузимати дъло то, кое за нъгга пріятніе... Трудолюбію противни два рода жизни: жизнь дълательнаго человъка, и разсьянія жизни [Арсич 1816: 82].

Кто можетъ говорити о трудолюбію, а не поминати всегда сельскую жизнь и науку? Ни гди трудолюбіе ніе тако пріятно, као въ сель; но никаковымъ предметомъ не можетъ онъ быти полезанъ и способанъ, као наукомъ просвъщеный [Арсич 1816: 87]. 
Отъ досуга весьма отлична праздностъ; сія посльдняя есть бездъйствіе, а досугъ есть вньшняя возможность произвольной, самоизбранной, и сльдсственно благороднъйшей дъятельности [Карамзин 1792а: 127].

Съ другой стороны уединеніе и прильъжне ученье скоръе всего могутъ наскучить въ городскихъ стенахъ, даже и тому, кто безъ помощи другихъ людей умъеть находить удовольствіе [Карамзин 1792a: 176].
Отъ трудолюбія весма отлична празность, льниваць ничего самъ способанъ обръсти, но аще что и насльдииъ, твердостію, безъ добродътели и благодъяния хранить [Арсич 1816: 83].

Но прильжное ученіе скоро можетъ украсити ю, и тако понравится ему и находитъ удоволствія, и кромъ градскихъ стьнахъ, способныхъ и разумныхъ людей [Арсич 1816: 89].

Во-вторых, Арсич архаизирует карамзинский стиль и включает в русский текст вставку о добродетельной жизни, написанную на славяносербском языке. Наконец, в-третьих, условием деятельного счастья в сельском уединении Арсич называет, в отличие от Карамзина-Гарве, не искреннего друга, любящего науки и природу, а благочестивую жену, разделяющую любовь своего супруга к учению и природе (программный перевод Карамзина превращается таким образом в апологию добродетельной семейной жизни, характерную для религиозно-моралистической традиции):

Карамзин: И когда есть у него другъ, который подобно ему любитъ Природу и Науку; естьли обстоятельства позволяютъ ему еще дъълать благодъяния н'ъкоторымъ людямъ, и служить другимъ: тогда въ сельской жизни своей будетъ онъ совершенно дъъятеленъ, и насладится всъъъ щастіемъ, которымъ человъ̌ъъ, по ограниченной своей натуръ, можетъ здъсь наслаждаться [Карамзин 1792а: 176].
Арсич: а еще коему осмъивается щастіе: имать ли супругу, любезнаго друга своего подобно ему, коя любитъ природу и науку; и когда обстоятельства дозволяют имъ, творити благодъянія нищимъ, и добродътелію служити другимъ, тогда въ селской жизни своей будетъ онъ совершенно дъятелен, и насладится всъмъ щастіемъ, коимъ человъъъ, по ограниченной своей натуръ, можетъ здъ наслаждатися [Арсич 1816: 89].

В свою очередь, полное отсутствие указаний на источники в книге Арсич свидетельствует об укорененности ее литературного сознания в старой книжной традиции, считавшей статус текста выше статуса автора [Левин 1995; Варда 2016]. Конечно, анонимные заимствования и так называемые литературные кражи были типичны или даже «пандемич- 
ны» для светской словесности XVIII в. [Рак 1998; Симанков 2015], но, в отличие от средневекового (точнее, барочного и ранне-просвещенческого) представления об авторстве, они в эту эпоху понимались как проблемные и не раз становились причиной литературных споров и скандалов [Николаев 2004]. Примечательно, что к концу этого столетия в русской сентиментальной традиции такие заимствования стали восприниматься как этически недопустимые. Так, Карамзин осуждал «некоторых из наших писцов, или писателей, или переводчиков» за то, что они поступают «непростительнейшим образом», обманывая простодушную публику на счет авторства публикуемых ими переводов: «Самая гражданская честность обязывает нас не присваивать себе ничего чужого, ни делами, ни словами, ни молчанием» [Карамзин 1791: 218].

Очевидно, что Арсич была крайне далека от представлений об авторстве, которые в 1810-е гг. более или менее утвердились в литературной традиции, откуда она заимствовала все тексты для своей книги. Старый принцип она применила к новому материалу, увенчав получившийся том своим собственным именем ${ }^{26}$.

В этой связи весьма показательным является почти дословное использование Арсич переводов самого Карамзина (последний печатал их анонимно, но указывал, откуда они были взяты). Так, в заключительную часть «Размышлений» она включает стихотворный диалог «Гроб», который польская исследовательница ее творчества, не знавшая о его источнике, назвала «средневековой моралистической сценой», разыгрывающей пессимистическое и оптимистическое представления о смерти [Косh 2007: 31]. На самом деле, это стихотворение Арсич является «несколько осербленным» переложением «Могилы» («Кладбища») Карамзина (в свою очередь, вольного переложения стихотворения немецкого поэта Л. Козегартена (1758-1818) «Des Grabes Furchtbarkeit und Lieblichkeit...»).

Судя по всему, это была первая публикация произведения Карамзина в сербской литературе, и потому имеет смысл процитировать ее полностью en regard с русским оригиналом.

26 Одной из главных задач перевода в XVIII в. была разработка возможностей национального языка, способного выразить «мысль» и «чувство» подлинника [Левин 1995; Рак 1998; Rosslyn 2000] и даже соперничать с более престижным языком переводимого текста. Таким образом, перевод превращался в своего рода «seizure of power, more than anything else, any transfer of anything at all» [Lefevere, Bassnett 1990: 8]. Между тем, Арсич имеет дело с очень близким ей и ее окружению языком. Перед нами явно не соперничество переводчика с языком более «продвинутой» культуры, но своего рода культуртрегерское заимствование, вполне законное в ее литературной среде, но анахроничное в контексте «престижной» европейской (и русской) литературы 1810-х гг. 


\section{Гробъ (1816)}

Первый Гласъ

Страшно во гробъ хладной и темной!

- Вътри дыхаютъ, гробы трясутся бълія кости, рушется.

Другій Гласъ

Тихо во гробъ, спящымъ спйоконо (sic!) Вътры дыхаютъ, прохладу даютъ, травки и цвътки на гробу растутъ.

Первый

Мравы и червы, точетъ умершыхъ, Въ мудрыхъ главъ жабе гнъздятся красоту тъла, зміи щипают点.

Другій

Крьпокъ сонъ мертвыхъ, сладостенъ кротокъ;

Во гробъ нъсть буры; нъжнія птыци пъсни на гробъ поютъ.

Первы й

Тамо обытаютъ черніе враны;

Алчныя птице; хищніе звъри,

Съ ревомъ копаютъ землю.

Другіи,

Мали чверчекъ во травъ зеленой, Со миломъ своіомъ дружиномъ тамо Отдыхаетъ, Голубъ спитъ на креспь умершыхъ.

Перв ый :

Запахъ со магломъ, густо мъшася. пливаютъ тамо въ воздухь душномъ, древо безъ лістія кодъ главе стоитъ,

Другій,

Тамо строется во воздухь свътломъ Пари благовонный любичици и любковъ босилка,

цвъткіи прекрасни муриса полніи.

Первый

Путникъ боится мертвой юдоли; ужасъ и трепетъ чувствуя въ сердцъ, мимо гробія спьшить

\section{Могила (1792)}

Одинг голосг.

Страшно въ могиль, хладной и темной! - Вътры тамъ воютъ, гробы трясутся, Бълыя кости стучатъ.

Другой голосу.

Тихо въ могил冬, мягкой, покойной.

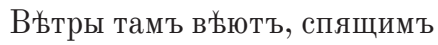

прохладно, Травки, цвьточки растутъ.

Первой.

Червь кровоглавый точитъ умершихъ, Въ черепахъ желтыхъ жабы гнъздятся, Зміи въ кропивь шипятъ.

\section{Bторой.}

Крьпокъ сонъ мертвыхъ, сладостенъ, кротокъ;

Въ гробъ н究ъ бури; нъ̌жныя птички Пъснь на могиль поють.

Первой.

Тамъ обитаютъ черные враны, Алчныя птицы; хищные звъри Съ ревомъ копаютъ въ земл点.

Второй.

Маленькой кроликъ въ травкъ зеленой Съ милой подружкой тамъ отдыхаетъ; Голубь на въ̌точкъ спить.

Первой.

Сырость со мглою, густо мњшаясь, Плаваютъ тамо въ воздухь душномъ; Древо безъ листьевъ стоить.

\section{Bторой.}

Тамо струится въ воздухь свътломъ Паръ благовонный синихъ фіялокъ, Бълыхъ ясминовъ, лилей.

\section{Первой.}

Странникъ боится мертвой юдоли; ужасъ и трепетъ чувствуя въ сердцъ, Мимо кладбища спґшитъ. 
Другій

Путникъ возлагаетъв крестное знаменіе, и сматра обытель въ̆чнаго міра, тамо остается на вьки

[Арсичь 1816: 154-156].
Bmорой.

Странник усталый видитъ обитель Въчнаго міра - посохъ бросая, Тамъ остается на въ̌ъ

[Карамзин 1792б: 109-111].

Хотя изменения, внесенные Арсич, являются незначительными (она скорее портит текст источника, нежели адаптирует его), несложно заметить, что «внутри» ее «Размышлений» это диалогическое стихотворение, принадлежащее кладбищенской поэзии XVIII в., включается в ряд лирических и нравоучительных медитаций о будущей участи человека и предваряет собой короткое стихотворение о «покое души», озаглавленное «Слово надъ гробное», и завершающий книгу прозаический «Тестаментъ», взятый из переведенных на русский бесед св. Иоанна Златоуста.

Иначе говоря, философия смерти, представленная в заимствованном из русской сентиментальной традиции стихотворении, оказывается составной частью гибридного барочно-просветительского образа благочестивой и мистически настроенной сербской писательницы, последовательно создаваемого в подписанной именем Арсич книге. Показательно, что разнородные литературные тексты, взятые ею из русских светских журналов, соединяются (сплетаются) друг с другом в ее сочинении с помощью стихов из Псалтири и заключительным словом «Полезных размышлений» является «Аминь» [Арсичь 1816: 159].

\section{5. Натурорилософоия Арсич}

Что же представляет собой философия природы в книге Арсич, вызвавшая столь лестные оценки исследователей? Особый интерес здесь представляет самый длинный натурфилософический текст, включенный в «Размышления», - девять фрагментов о созерцании природы, истечении эфира из атмосферы, молчании натуры, будущих откровениях, кровообращении, «соке нервъ» и воздушных каналах, по которым созревшая душа человека переходит в вечность. Именно в этих физиолого-метафизических резиньяциях исследователи обнаруживают недюжиный философский дар первой сербской писательницы («an intriguing mixture of scientific language with philosophy and ethics» [Hawkesworth 2000: 96]), ее энциклопедическую ученость, крайне редкую для сербской женщины того времени [Косh 2007: 32-33] и вообще уникальную для балканской культуры начала ХІХ в. [Петровић 1959: 69].

Как мы знаем, Арсич этот текст не сочиняла и не переводила, но практически дословно воспользовалась напечатанными в русском 
журнале «Иппокрена» философскими фрагментами полунатуралистического-полумистического сочинения об «экономии природы, которая относится собственно к человеку, а особливо к его участи после сей жизни» [Приятное и полезное..., 1797: 189]. Эта публикация давно атрибутирована Феофилакту Покровскому - «философу горы Алаунской», тульскому учителю юного В. А. Жуковского и чувствительному собеседнику помещика-литератора А. П. Орлова, автора ультра-сентиментальных «Утех меланхолии» ${ }^{27}$. В очерке, посвященном Покровскому, Н. С. Тихонравов предположил, что его сочинение представляет собой либо переложение «Созерцания природы» Шарля Бонне, либо собственную вариацию «Алаунца» на натурфилософские темы [Тихонравов 1898: 35]. Татьяна Нешумова также связывает общие размышления Покровского о явлениях физического мира (кровообращение, движение тела под действием силы и т. п.) с трудами швейцарского естествоиспытателя [Нешумова 2007: 27].

Между тем, как нам удалось установить, Покровский пользовался другим источником, имевшим мало общего с философией природы знаменитого ученого-натуралиста (не связан он и с влиятельной «Экономией природы» Карла Линнея). На самом деле тульский учитель и сочинитель перевел первую часть анонимной немецкой брошюры 1782 года «Die Öekonomie der Natur», озаглавленную «Über den Menschen und sein Schiksal nach dem Tode» (возможно, с французского перевода 1783 г.). Автором этого странного сочинения, представлявшего собой полемику с материализмом в целом и с «Système de la nature» Поля Гольбаха в частности [Curran 2012: 181], был датский дипломат барон Андреас Петер фон Бернсторф (Andreas Peter von Bernstorff) ${ }^{28}$.

Вернемся к философическим рассуждениям Арсич. Мы видим, что ее книга является не только языковым, но и идеологическим коктейлем, в котором смешаны самые разные по своему происхождению ингредиенты. Популярный церковно-славянский сборник поучений о добродетели «Ифика Иерополитика», духовная поэзия Псалтири, беседы Иоанна Златоуста и молитва митрополита Платона, фрагменты из

27 Философские отрывки из созерцания природы // Иппокрена. 1799. Ч. I. 97-120, 129-134, 146-150. [Библиографическое описание было выше, может быть, здесь убрать?] Первая часть перевода Ф. Покровского, вышедшая ранее в «Приятном и полезном препровождении времени» (Иппокрена. 1797. Ч. 14-15), не привлекла внимания Арсич.

28 Эта книга была переведена на французский и английский языки и вызвала ряд едких критических откликов (см.: L’année littéraire [1783]. Vol. 4. P. 290-315). Английский рецензент этой книги назвал ее «[A] strange whimsical rhapsody about nature and natural operations by an honest German, unacquainted with the most common facts» [The Critical Review 1791: 357]. Об атрибуции этой книги Бернсторфу см.: [Barbier 1822: 358; Nowitzki et al. 2018: 421]. 
Бюффона и «Боннетова Созерцания природы» в переводе Карамзина, его же переложение томсоновских «Времен года», русские выдержки из философии «дамского писателя» Вейсса и юнговых ночных дум соединены в этой книге с мистической натурфилософией маргинального немецко-датского автора, переведенного на русский язык провинциальным учителем и философом-дилетантом.

Между тем, у этого смешения идей есть своя внутренняя логика или, точнее, задача. Новое (для молодой сербской литературы) вино Арсич разливает в старые мехи. Функция (натур)философских заимствований в ее книге заключается не столько в ознакомлении читателя с новейшими научными открытиями в физике, биологии, анатомии и проч., сколько в иллюстрации с помощью заимствованных примеров основных религиозных догматов и барочных аллегорий (мир как театр; возрасты или степени жизни-года-природы-бытия). Действительно, вся «научность» заключающего ее книгу трактата сводится к утешительному обращению сочинительницы к несчастным людям, «коих смутни часы поваждает меланколия с всемо следствиями» [Арсичь 1816 144]. Приведем это обращение en regard с его русским источником:

\section{Арсич}

(релігія) законъ есть превосходнъйшая утьшительница; она говоритъ о будущей жизни въ величественіихъ писаніяхъ, изсльдывающій духъ хоть⿻丷丶 тако узнати, фузіческую возможность дъла. Къ сему я толико способствова, колико могохъ, садъ схожду съ (театра) позорища, и одтаю своя испытанія изсльъдованію человъькомъ разумнымъ [Арсичь 1816 145].

\section{Ф. Г. Покровский}

Религія есть превосходнъйшая утьвшительница; она говоритъ 0 будущей жизни въ величественныхъ картинахъ. Изсльдывающій духъ хочетъ также узнать физическую возможностъ дъ่ла. Къ сему я столько способствовалъ, сколько могъ. Теперь схожу съ театра и отдаю свои испытанія изсль'дованію людей разумныхъ [Иппокрена 1799: 150].

Еще одной - если не главной - функцией философических резиньяций в «Полезных размышлениях» является своеобразное повышение авторского статуса их сочинительницы, которая оказывается способной не хуже писателей-мужчин говорить на высокие метафизические темы в рамках все еще влиятельной в сербской литературе церковно-книжной культуры.

В то же время архаизирующее озвучивание Арсич чужого текста (вдвойне чужого - ведь она пользовалась русскими переводами английских, немецких и французских сочинений) не только свидетельствует об укорененности ее авторского сознания в старой книжной 
традиции. Парадоксальным образом это цитирование представляет собой крайний случай показательного для предромантизма литературного усвоения (апроприации) заимствованного произведения, когда «чужое» начинает выражать и моделировать «свое», говорить о «собственных» мыслях и чувствах переводчика и учит читателя «правильно» выражать свои мысли и эмоции [Топоров 1981; Зорин 2016; Vinitsky 2015]. Причем, как показывает опыт Арсич, чем ближе язык оригинала к языку переводчика, тем, вероятно, легче и естественнее оказывается сам процесс вживания в «чужое» и выстраивание собственной литературной личности (мы бы назвали последний «эффектом Пьера Менара» - борхесовского героя, переложившего «Дон Кихота» с испанского на испанский с целью создания собственной авторской индивидуальности).

\section{6. Партия сочинительницы}

Рассмотрим образ создательницы «Размышлений» в актуальном для него историко-литературном контексте. Следует подчеркнуть, что литературная биография Арсич подозрительно коротка и, по сути дела, сводится к двум годам. В 1814 г. 38-летняя жена арадского градоначальника-просветителя и сторонница просвещенного Досифея публикует свою первую книгу, посвященную инспектору народных православных училищ в Пеште и Араде, только что представившему ее мужа к имперской награде. Потом она печатает вторую книгу и умолкает до конца своей долгой жизни. Первой сербской писательницей она названа была, как мы помним, в оде 1815 г., написанной по случаю получения супругами Арсич венгерского дворянства за просветительскую и благотворительную деятельность. После выхода второй книги Арсич ее имя включается в список новейших сербских сочинителей, составленный одним из покровительствуемых арадской четой авторов. Другой автор ее круга, посвятивший свой перевод из Виланда Арсич как «ревностной сей книги помощнице», ранее поднес, по ее поручению, 400 экземпляров «Полезных размышлений» в дар Сомборским подготовительным училищам [Гавриловић 1970: 364-365].

После смерти Саввы Арсича (1824) выходит в свет только одна нравоучительная статья Евстахии (1829), также, по всей видимости, составленная из переводов и неизвестно когда написанная [Арсичъ $1829]^{29}$. Конечно, можно допустить, что ею были сочинены и какие-то

29 В состав этой дидактической статьи вошли 6 кратких притч и поученией: «Старацъ и три младића» (несомненно, адаптация одноименной басни Лафонтена, популярной и в русской литературе XVIII в.: И. И. Дмитриев, Д. И. Хвостов), «Благоразумие», «Праведльивость», «Мужество», «Умереность», «Благопристойность», «Честность». 
другие, не дошедшие до нас произведения ${ }^{30}$, но факт остается фактом: как писательница Арсич возникла и исчезла в период с 1814 по 1816 г., и ее скромная литературная деятельность тесно связана с начальным периодом в истории сербских и валахских православных школ в Австрии и пропагандой сербского мужского и женского образования последователями Досифея Обрадовича ${ }^{31}$.

Знаменательно, что обе книги Арсич появились в период активизации сербского книгоиздательства в Габсбургской империи, совпавший с окончанием наполеоновских войн, политикой австрийских властей в поддержку сербского народного просвещения и быстрым развитием второго сербского восстания против турок, поддержанного Российской империей и закончившегося признанием внутренней автономии османских сербов ${ }^{32}$. По нашим подсчетам, только с 1814 по 1816 г. в Будиме вышло около 50 книг гражданской печати на славяно-сербском языке, написанных в самых разных жанрах, причем заметную часть этих сочинений составляли переводы или переделки русских произведений и оды, посвященные сербскими авторами российскому царю - победителю Наполеона и освободителю Европы - и его австрийскому и прусскому союзникам [Новаковић 1869: 94-106] ${ }^{33}$.

Восторженные (несомненно, навеянные русской поэзией XVIII в. от Ломоносова до Карамзина) стихи о России - помощнице сербского народа и примере успешного решения стоящей перед сербами задачи национально-культурного становления - писал на славяно-русском (иногда почти не отличимом от русского) языке Григорий Якшич - автор оды в честь Арсич и ее мужа ${ }^{34}$ :

${ }^{30}$ Б. Панич предположил, что Евстафия была автором трогательной стихотворной эпитафии, выбитой на надгробии ее матери и мужа [Панић 2015: 72]. Сохранились письма и завещание Арсич, краткие воспоминания о ней современников и сведения о ее благотворительной деятельности в Араде [Idem 2014]. Биографические сведения об Арсич собраны в [Бугарски 2014; Idem 2016].

31 Хотя первую школу для сербских девочек повелела завести еще императрица Мария-Терезия в 1770-е гг. [Павић 1979: 77], историю систематического женского образования в Сербии обычно отсчитывают с 1840-х гг. [Dojčinović, Pantelić 2014: 122].

32 Третья фаза, выделяемая Павичем в истории габсбургского просветительства славянских подданных империи [Павић 1979: 76-77].

33 Характерный пример такого сербско-русского творчества представляют собой стихи Г. Якшича, вышитые по канве державинской песни: «Громъ побъды разгласися, / Да ликуетъ храбрый Русс, / Святый союзъ да хвалится, / Совокупно съ ними Пруссъ, / Славу Князей и союза / Да возвьститъ моя муза» [Якшић 1814: 1].

34 Эпиграф к этой оде Якшич взял из патриотического стихотворения архимандрита Лукиана Мушицкого, посвященного сербскому литературному возрождению («Михаилу Вишковичу», 1811). 
Грядетъ въкъ златый и блистаетъ

Парнасъ, приходомъ веселитъ;

Отрадъ источникъ изливаетъ,

Трудящымся славу дъљлитъ.

Грядетъ, и волнами Дуная

Къ Нептуну въ черный Понтъ бъжитъ,

Оттуду ж' сія въсть новая

Ко хладному Норду* [сноска: Россіа. - И. В.] спьшитъ.

[...] Не музы л' кротки сему виною?

Что Россіа уже цвътетъ,

Просвъъщенье есть причиною,

Что знаній свътъ ныне блестетъ.

[...] В средъ зависти, в средъ гоненья

- Созръль и у насъ наукъ плод,

Как Досифеа была желанья, -

Отверзаетъ темность нашъ Родъ.

[...] Въ дни наши узримъ вь̌къ сатурній,

Возникнетъ Греціа и Римъ.

На брезъхъ Дуная Афони

Увидимъ и Іерусалимъ.

О том, что «Размышления» Арсич вписываются в контекст патриотической сербской литературы того времени, свидетельствует интерполяция, посвященная «многомудрому и милостивейшему» австрийскому императору, пекущемуся о народном просвещении и «преимуществах художников», и его отважному воинству, одно имя которого вызывает скрежет зубовный в роде Мохамедском. В эту вставку также включена апология душеполезного чтения и красот «славянского языка»:

[M]ожемо ли чувствованія наша утаити отъ новина на нашемъ матернемъ езыку, изъ коихъ сва Царства, Цареве, мъста, и градове, сраженія, Польководце, наше Бранителъ познаемо Чтеніемъ нарави наше украшавамо, мысли обогащавамо, домостроеніемъ мудро управлямо, у трудолюбію прильжавамо, мысмо домохранителнице, као матице у кошницы [Арсичь 1816: 13].

Впрочем, едва ли и эту эмоционально-заряженную вставку (равно как и другие интерполяции на эту тему) можно назвать оригинальным (в современном смысле слова) творчеством Арсич. Перед нами не столько характерное для переводов XVIII в. «склонение» на национальные нравы или «подражание литературному авторитету с добавлением “от 
себя” [Николаев 2004: 6], сколько парафраз апологетических описаний мудрых жен, которые мы находим в церковно-славянской нравоучительной литературе и просветительских сочинениях Досифея.

Исследователи женской литературы в славянских странах [Blas 2014: 136; Francikova 2017: 10-11] обращают внимание на тот факт, что для формирования национальных культур первой трети XIX в. был характерен запрос на образ женщины-писательницы (некоторые феминистские критики видят в этом запросе своего рода wishful-thinking и форму контроля над женской субъективностью со стороны авторов-мужчин [Alexandrova 2014: 160-162]) $)^{35}$. В отдельных случаях, как показал чешский ученый В. Мацура, этот культурный запрос приводил к созданию фиктивных писательниц, причем одним из способов такого мифотворчества было приписывание реальным женщинам (иногда уже отметившимся какими-либо сочинениями) произведений, написанных мужчинами от их имени ${ }^{36}$.

Не были ли амбициозные «Полезные размышления» мистификацией, созданной кем-то из патриотически настроенных арадских или пештских литераторов и опубликованной и распространяемой, с согласия самой Арсич, от ее имени? Иначе говоря, не является ли Арсич реально существовавшая образованная женщина, сочинительница маленькой нравоучительной книжицы и добродетельная супруга арадского благотворителя и директора народных приготовительных училищ - такой полезной для общенационального дела литературной маской или, перефразируя выражение Ю. Н. Тынянова, «мнимой» ${ }^{37}$ (точнее, полумнимой) писательницей и философкой?

У нас нет материальных подтверждений этой исторически вполне правдоподобной гипотезе, но совершенно очевидно, что в театре современного мира (любимая барочная метафора Арсич) «имплицитный автор» (implied author) «Размышлений» играла «завещанную» Досифеем Обрадовичем роль благочестивой просвещенной жены-матери,

35 Так, молодой русский поэт Жуковский инициировал и контролировал переводческую деятельность своих родственниц Вельяминовых, а затем Протасовых [Vinitsky 2015: 58-60]. О значении переводов, сделанных женщинами в России XVIII в., см.: [Rosslyn 2000]. Сентименталистские истоки русской женской литературы рассматриваются в исследовании Урсулы Штолер Disrupted Idylls [Stohler 2016].

36 О чешских примерах см.: [Macura 1995: 110; Francikova 2017: 10-11]. В русской традиции одной из первых фиктивных сочинительниц была придуманная издателем «Журнала для милых» Анна Безнина, «урожденная кроатская княжна “Трубеска” » [Вацуро 2002: 400]; по всей видимости, полумистификациями являются литературные образы Елизаветы Кульман [Лосева 2012: 20] и Сарры Толстой.

37 «Меньше всего я способен отрицать значение мнимых величин в литературе. Поэтому вымышленные, отраженные поэты становятся реальностью» [Тынянов 1977: 538]. 
дарящей своими полезными и мудрыми словами достигших национально-культурной зрелости соотечественников и соотечественниц ${ }^{38}$. И в этом действе не является существенным то, что «исчадия нежнаго чувствования» имплицитной сочинительницы «Размышлений» частично или целиком взяты из разных русских журналов и сборников, ведь это и есть ее заученная, присвоенная и отвечавшая ожиданиям ее преимущественно мужской аудитории литературная партия.

\section{7. Феминизация как прием³9}

Собственно говоря, на сцену своего центонного сочинения «первая сербская писательница» выходит крайне редко. В ее книге всего несколько более или менее пространных интерполяций: обращение от лица женщины к читателям (см. эпиграф к этой статье), вставка о роли матери с полемической отсылкой к церковно-славянской «Ифике Иерополитике» (в заимствованном у Карамзина переложении «Осени» Томсона!), славословия сербским женщинам, родному языку и австрийскому императору (в одном случае Арсич заменила дифирамб Александру I на гимн его августейшему австрийскому союзнику Франциску I - «Избавителю Еvропе, и Освободителю кровопролитія рода человьческаго, кое двадесять льтъ невинно проливася» [Арсичь 1816: 3] $)^{40}$.

Помимо этих вставок, в книге используется небольшой набор приемов, создающих иллюзию присутствия и оригинальности его объявленной на титуле сочинительницы. Приведем несколько характерных примеров такой литературной «материализации» автора.

Исследователи отмечают, что описание каждого времени года в тетралоге Арсич «Четыри времена годишня» открывается стихотворным зачином, предваряющим дальнейшее метафорическое, политическое или научное развитие соответствующей темы [Миланков 2001: 164;

38 В своих сочинениях Досифей постоянно обращался к теме женского образования и роли просвещенных женщин в свете - от Коринны, девицы Фивейской, состязавшейся в поэзии с Пиндаром, и мудрой Аспазии, которую Сократ называл своим учителем, до Елизаветы Английской и Екатерины Великой [Обрадовић 1807: 152]. Показательно, что саму Арсич прозвали «женски Доситеј» [Радовановић 2006: 30; Кох 2012: 32].

39 О феминизации литературы в сентименталистскую эпоху см.: [Vowels 1994]. В случае Арсич феминизация литературного текста не ведет к созданию языка и образа современной европейской чувствительной женщины. Целью этого приема является создание образа благочестивой просвещенной и патриотически настроенной жены.

40 Ср.: «[Ч]теніемъ всякій часъ одохновенія можесе услаждавати, у светковне дне, и дуге зимнь ноћи, Церковне книге возводе сердца наша къ Богу, и ползуемое у Славенскому езыку, книге Церковне духомъ святымъ чрезъ Писателе писане, духу Божію у человьку обитающу открываютъ премудрость, и волю къ заповьдемъ Божіимъ» [Арсичь 1816: 14]. 
Koch 2007: 31; Hawkesworth 2000: 95]. Одна из «песен» этого тетралога, «Весна», была даже помещена в антологию старой сербской поэзии 2004 г. как оригинальное стихотворение [Милосављевић 2004].

Вот начало этого текста в книге Арсич:

Створителю тебъ хвала буди

на дарма,

Красна весна садь настае

весель свима,

Гонитъ зиму жестокую

къ съ̌веру,

Являются пріятная нама

времена

Солнце жарко посылаеть намъ

лучи своя,

Жаромъ своимъ растопляетъ

снъжныя груды,

Превращаетъ ихъ въ солную воду,

Горы зеленыя главы своя

движутъ къ небесамъ

Веселися о юносте

весна настае!

Хвалу подай Сотворителю щедрому.

- Много пути еще возвращается зима, съ бурями своими доноситъ мразъ на бльдое ютро...

[Арсичь 1816: 23-24].

Несложно заметить, что в основе этих стихов, предваряющих прозаический текст, - первые предложения карамзинской «Весны» (как уже указывалось, вольное прозаическое переложение первой части поэмы Дж. Томсона «Времена года»), разбитые на стихотворные строки и (с некоторыми отклонениями) силлабически ритмизированные:

Наступаетъ весна и гонитъ къ северу жестокую зиму. Вездъь является пріятная перемена. Солнце возвышается, низпосылаетъ лучи свои на землю гораздо прямъе, жаромъ своимъ растопляетъ снъжныя громады и превращаетъ ихъ въ мутную воду, а горы воздымаютъ къ небесамъ зеленъющияся главы свои.

Часто еще возвращается зима съ бурями своими и налагаетъ цепи мраза на бльдное утро... [Карамзин 1787б: 195].

Такими же псевдооригинальными стихами, выделенными, очевидно, с целью придания большей эмоциональности философским медитациям лирической героини, начинается и завершающая тетралог Арсич «Зима»: 
Возлюбленная нъжжная сердца

Юности,

Пъвала самь вамъ радости

весенныя,

Веселое красно льтто и влажну

есенъ,

Садъ воспьвамъ сердцамъ вашимъ

грозную зиму,

Посльъдную пъснь мою

егда умолкну.

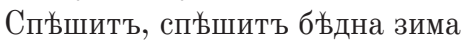

жизни моея.

Хладнъютъ нервы моя, въщаютъ

конецъ,

Скоро, скоро смерть грозная

Сразитъ мя косомъ,

Не остаеть отъ существа

токмо хладный прахъ,

Споменте мя со пъснми

Любимцы музы,

Се существо намъ пъвала

пріятни пьсни,

Ту я жертву потребуемъ благодарности.

- Спъшитъ, спъшитъ мрачная зима, провождаема парами, облаками и бурею. Благословлю тебе мрачность, мнъ сродственная!

[Арсичь 1816: 71-72].

Опять же, Арсич здесь не сочиняет, но варьирует и разбивает на стихотворные строки прозаический зачин «Зимы» Карамзина:

Сп究шитъ, спґшитъ мрачная Зима, провождаемая парами, облаками и бурею. Благословляю тебя, мрачность, мнъ сродственная! благословляю васъ, ужасы зимніе, среди коихъ я родился! Въ часы радостнаго утра жизни моея, воспитываемый въ безпечномъ уединеніи, радостно пробъгалъ я области твои, о Зима! ступалъ по чистому снъгу, имъя чистую душу; внималъ шуму вътровъ, не заглушаемому шумомъ страстей, коихъ имена мнъ едва извъстны были. Пріятное воспоминаніе, извлекающее теперь слезы изъ глазъ моихъ! [...] Юныя сердца! я пълъ вамъ радости Весеннія, веселіе Лъта и пріятную важность Осени: теперь воспою вамъ грозную Зиму, посльднюю пъснь мою, и навсегда умолкну. Спъшитъ, спъшитъ Зима жизни моея: хладъющая кровь моя возвъщаетъ ея приближеніе. Когда же грозная смерть сразитъ меня своею косою; когда въ семъ міръ отъ существа моего останется единый хладный прахъ: тогда, о любимцы Музы моея! тогда посътите могилу мою, омочите ее жаркою 
слезою и скажите: пъвецъ, котораго кости здъсь покоятся, воспъваль намъ пріятныя пъснни. Вотъ единая жертва, которой требую отъ благодарности вашей! [Карамзин 1797в: 193].

Одним из самых характерных приемов Арсич является более или менее последовательная замена мужского рода оригинала на женский, с помощью которой создается иллюзия «личного» (здесь - женского) впечатления от меняющейся природы (напр., «певала» вместь «пель»).

Подобную феминизацию мы наблюдаем и в других «переводах» Арсич, включенных в ее «Размышления»:

Какъ вгъчность можетъ принадлежать толь бренному существу?

[Картина бытия 1798: 13].

Безразсудный! я обтијал себъ постоянныя удовольствія на премънчивомъ позорищъ міра [Картина бытия 1798: 18].
Како можетъ в Һччность принадлежати толь бренному существу, мне, неим ъющей ни часа собственнаго? [Арсичь 1816: 148].

Безрасудная! я обтиава себъ постояная удоволствія на примъчивомъ позорищъ мира [Арсичь 1816: 151].

(Позволим себе «в скобках» привести аналогию, наглядно иллюстрирующую гендерную апроприацию, используемую в книге Арсич. Представим, что пушкинские стихи «Я вас любил безмолвно, безнадежно, / То робостью, то ревностью томим; / Я вас любил так искренно, так нежно, / Как дай вам бог любимой быть другим» переложены были бы на родственный славянский язык так: «Любила вас безмолвно, безнадежно, / То робостью томима, то тоской; / Любила вас тако искренно, тако нежно, / Као дай вам Бог любимым быть другой». Причем прелагатель этих строк не сослался бы на поэта П. и опубликовал их как свои собственные...)

Надо сказать, что феминизированные переложения Арсич действительно ввели в заблуждение ее немногочисленных исследователей. Так, заключительная строфа процитированных выше «стихов» Арсич о «Зиме» приводится в работах о ней как образец ее оригинального творчества - своего рода завет первой женщины-писательницы потомкам:

Спомените мја со пјесними,

Љубимци музи,

Ту ја жертву потребујем

Благодарности

[Петровић 1959: 70].

Между тем, как мы видели, эта строфа представляет собой «оверсифицированный» прозаический текст Карамзина: «[Т]огда, о любимцы 
Музы моея! [...] скажите: пъвецъ, котораго кости здьсь покоятся, воспьвалъ намъ пріятныя пьсни. Вотъ единая жертва, которой требую отъ благодарности вашей!» [Карамзин 1797в: 193].

Наконец, псевдооригинальным стихотворением оказывается, как мы полагаем, и публикуемое в нескольких антологиях сербской поэзии «Слово надъ гробное» Арсич, являющееся, по всей видимости, адаптацией русского переложения антологических стихов, завершающего третий том популярного в России романа А.-Р. Лесажа:

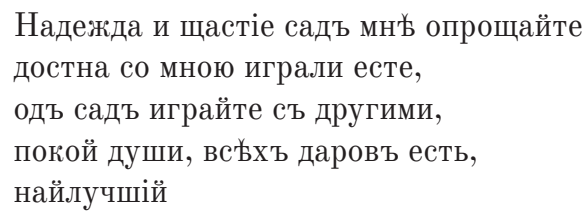

[Арсичь 1816: 156].

Ср. русскую версию этой эпитафии, использованную Г. Р. Державиным в качестве эпиграфа к одному из своих посланий:

\author{
Надежда, счастие прощайте. \\ Довольно вы играли мной, \\ Теперь другими вы играйте, \\ Меня пустите на покой \\ [Гуковский 1933: 382].
}

\title{
8. Лирическая героиня
}

«Казус Арсич» свидетельствует о том, что нельзя доверять без филологической проверки авторским репутациям, сложившимся в определенных исторических условиях, только потому, что они отвечают ожиданиям современников и убеждениям исследователей. В то же время, с историко-литературной точки зрения «жертву благодарности» потомков Евстахия Арсич, безусловно, заслуживает, но только не за приписываемые ей современными авторами оригинальность, европейскую энциклопедичность, космополитичность, философско-поэтический и переводческий талант. В конечном счете «Полезные размышления» являются не барочным «вертоградом», литературной кражей, мистификацией, центоном, «менаровским» палимпсестом (Борхес), трансплантацией [Лотман 1985], «фонетическим переводом» [Macura 1995; Cooper 2014] или адаптацией к сербским условиям русского нравоучительного сентиментализма конца 1790-х гг., но амбициозной (хотя и архаичной и механической) попыткой «скомпоновать» на основе 
усвоенных и присвоенных текстов из русских журналов той эпохи эквивалент сербского литературного и духовно-философского языка, выражающего образцовые мысли и чувства ученой и благочестивой женщины-писательницы, появление которой предсказывал Досифей Обрадович. Если использовать современный термин, то можно сказать, что это был своего рода культурный проект, ставивший целью заполнить вакансию национальной поэтессы - европейски образованной патриотки, разделяющей жизнь, труды и убеждения своего супруга ${ }^{41}$. В самом деле, подобных рассмотренному нами случаев гораздо больше и вполне можно говорить об общем для зарождающихся национальных культур феномене искусственно созданной (как в приводившихся выше чешских и русских примерах) или мифологизированной (как в случае Арсич) писательницы.

Удался ли этот эксперимент? В исторической перспективе «Размышления» Арсич, как и другие произведения близких ей авторов, ориентировавшихся на книжный славяно-русский язык, оказались лебединой песней сербской литературной практики XVIII - начала XIX в. Реформа В. Караджича (ориентация сербского литературного языка на живой «простонародный») пресекла тесную связь сербской образованной элиты с русской литературой. Архаичная по своему языку, жанру и содержанию книга Арсич была совершенно забыта. И все же важная часть этого парадоксального сочинения убежала от тлена - полуфантомное имя его создательницы на титульном листе книги как знак новой «лирической героини», введенной Арсич (или ее сочувственниками и сотрудниками) в сербскую литературу. Впоследствии этот образ удачно вписался в традицию романтического национализма XIX в. (своего рода сербская мадам де Сталь) и оказался актуален для современных феминистских и гендерных исследований ${ }^{42}$.

41 В этом отношении русская литература XVIII в. представляла собой не только источник, но и образец - и в какой-то степени антитезу - для формирующейся сербской. Со второй половины XVIII в. русские женщины-литераторы активно участвовали в культурном процессе (от княгини. Дашковой и императрицы Екатерины до образованных провинциальных помещиц-литераторов; см.: [Владимиров 1892; Rosslyn 2000; Glagoleva 2003; Kelly 2002]). Каталог российских писательниц Руссова [1826] включает сведения о 97 авторах-женщинах. Венди Росслин насчитывает 120 переводчиц в XVIII - начале XIX в. [Rosslyn 2000: 33]. Между тем ни одна из русских писательниц и переводчиц XVIII в., насколько нам известно, не выдвигалась идеологами новой русской словесности на мифологическую роль первой национальной писательницы (причем хронологически первой русской писательницей назывались разные авторы - от «неизвестной поэтессы Петровского времени» [Позднеев 1971: 277-295] и царевен Натальи Алексеевны и Елизаветы Петровны до Е. А. Княжниной-Сумароковой и «Российской де Ля Сюз» Е. В. Херасковой [Владимиров 1892: 24-26]).

42 Заметим, что «первичная» мифологизация Арсич, относящаяся ко второй половине 1810-х гг., отличается по своему содержанию от последующих 


\section{Заключение}

Тридцать лет тому назад академик Н. И. Толстой с сожалением отметил, что исследователями «не проделана важная работа: не приведена полностью литература на церковнославянском и "российском" языке, изданная в России, подвергнутая сербами редактированию или так называемым “переводам”, и не произведен параллельный анализ языка оригиналов и переводов». Продолжительный «славяно-сербский» период, отмечает Толстой, - «очень любопытный сам по себе и важный также для понимания последующего крупного этапа истории сербской культуры - этапа национального возрождения», - до сих пор остается «малоизученным и односторонне освещенным» [Толстой 1988: 212].

Причину научной маргинализации этого периода Толстой видел в том, что филологи смотрели на «славяно-сербский» как на язык «"искусственный”, чужой, мало что дающий для изучения подлинно сербской речи» [Толстой 1988: 212], в то время как литературоведы считали «славяно-сербскую» литературу привнесенной извне, «не имевшей глубоких национальных корней» и едва ли не лишенной художественной ценности. Толстой ссылается на мнение Й. Скерлича о том, что за небольшим исключением вся сербская литература того времени - «литература только по названию, из-за убожества, из-за недостатка чеголибо иного и лучшего; все это только первая подготовка и закладка фундамента для настоящей литературы, которая возникнет (придет) только в XIX веке» [Толстой 1988: 174].

Как нам представляется, предложенные в нашей работе наблюдения и размышления не только устанавливают прямые источники «славяно-русской» книги «первой сербской писательницы» и описывают процесс усвоения и присвоения «родственного-чужого» как стадию национального и литературного самоутверждения «молодой» культуры, но и дают материал для более общего - филологического и литературоведческого - исследования «славяно-русского» периода в истории сербской литературы в частности и «панславянского» предромантизма в целом. Случай Арсич, которая, как мы полагаем, весьма удивилась бы, если бы смогла прочитать, попивая чай из фарфоровой чашечки со своим портретом, то, что написано о ней в нынешнем веке, также может быть интересен и для сравнительного исследования формирования

\footnotetext{
романтической и феминистской версий. Собственно говоря, в своей ранней ипостаси Арсич была просто первой женщиной, писавшей по-сербски, необходимой патриотически настроенным сербским просветителям, приветствовавшим наступление «века сатурнего» на Балканах. В свою очередь, в романтической интерпретации ее образа акцент ставился на печальной судьбе образованной и одаренной сербской женщины. Наконец, феминистскую критику она привлекает как первый женский голос в сербской культуре нового времени.
} 
национальных авторских «пантеонов» и гендерной истории русской и других славянских литератур.

Что же касается вопроса о том, является ли Арсич сербской Коринной (Сафо, Диотимой, де Сюз, Жанлис, де Сталь, Эльжбетой Дружбацкой, Боженой Немцовой, Жорж Санд или Черубиной де Габриак), мы сознательно оставляем его решение на усмотрение просвещенных читателей и читательниц.

\section{Библиограсрия}

Арсичъ 1814

Арсичъ Е., Совптъ матерній предрагой обоего пола юности сербской и валахійской, аки исчадіе нпжнаго чувствованія, имже благо и щастіе отрасли рода своего обимаетъ сочинителница, Будим, 1814.

1816

Арсичь Е., Полезная размышленія о четырехъ годишнихъ временехъ, съ особеннымъ прибавленіемъ о Трудолюбіи человека, и оттуду происходящей всеобщей ползе, сочиненна и на светъ издана Еустахиею отъ Арсичь, Будим, 1816.

$-1829$

Арсичъ Е., Морална поученија, Летопис Матище српске, 5, 19, 1829, 106-118.

Арсић 2013

Арсић Е., Полезна размищљања, Бугарски С., превео, приредио и допунске текстове написао, Темишвар, 2013.

Берић 1820

Берић П., Виландовъ Агатонъ, Будимъ, 1820.

Боичъ 1815

Боичъ Л., Памятникъ мужемъ у славено-сербскомъ княжеству славнымъ, 1, Будим, 1815.

Бугарски, Степанов 2014

Бугарски С., Степанов Љ., Еустахија Арсић поново међу нама, Арад кроз време: зборник радова са међународног научног скупа Арад 13-14. септембра 2013. Темишвар, 2014, 105-112.

Бугарски 2016

Бугарски С., Милан Ж., Лексикон срба кньижевника са данашнье територије Румуније 1705-2015, Темишвар, 2016.

Варда 2016

Варда А., Литературная жизнь России XVIII - начала XIX века, Lodz, 2016.

Варга 2001

Варга Л., Мозаик житеља Иришких, Нови Сад, 2001.

Вацуро 2002

Вацуро В. Э., Готический роман в России, Москва, 2002.

Владимиров 1892

Владимиров П. В., Первые русские писательницы XVIII века и участие русской женщины в развитии, Киев, 1892.

Вулетич 1976

Вулетич В., Н. М. Карамзин и литература сербского возрождения, Сравнительное изучение литератур: Сборник статей: К 80-летию акад. М. П. Алексеева. Ленинград, 1976, 108-116. 
Вуичь 1833

Вуичъ І., Животоописание и чрезвичайна нъгова приключения, Карлштадт, 1833.

Гавриловић 1970

Гавриловић С., Из преписке спрске кньижевнице Еустихије Арсић, Зборник матице спрске за кньижневност и језик, 18, 1970, 363-366.

Гудков 1977

Гудков В. П., Особенности воспроизведения русских текстов в «Славено-сербском

Магазине» - первом сербском журнале, Вестник МГУ. Филология, 1, 1977, 57-69.

Гуковский 1933

Гуковский Г. [А.], Литературное наследие Г. Р. Державина, Литературное наследство, 9/10, 1933, 369-396. $-2001$

Гуковский Г. А., К вопросу о русском классицизме. (Состязания и переводы), Idem, Ранние работы по истории русской поэзии XVIII века, Москва, 2001, 265-269.

Добрицын 2008

Добрицын А., Вечныйжанр: западноевропейские истоки русской эпиграммы XVIIIначала ХІХ века, Bern, 2008.

Доронина 1989

Доронина Р. Ф., Мушицкий и Державин, Русско-сербские литературные связи XVIII начала ХІХ века, Москва, 1989, 145-160.

Достян 1989

Достян И. С., Издание и распространение в России произведений сербских авторов (XVIII - начало XIX вв.), Русско-сербские литературные связи XVIII - начала XIX века. Москва, 1989, 8-24.

Живаљевић 1891

Живаљевић Д., Друга књига Јевстахије Арсићке, Јавор, 9, 1891, 141-142

Заболотский 1908

Заболотский П. А., Очерки русского влияния в славянских литературах нового времени. 1. Русская струя в литературе сербского возрождения, Варшава, 1908.

Зорин 2016

Зорин А. Л., Появление героя: из истории русской эмоциональной культуры конца XVIIIначала ХІХ вв., Москва, 2016.

Иппокрена 1799

Просвещение наций и человеческого рода, Иппокрена, или Утехи любословия, 3, 1799, 33-40.

Јовићевић 2014

Јовићевић Т., Глас из потиснутог наслеђа, Књиженство, часопис за студије књижевности, рода и културе, 4, 4, 2014, 91-111.

Карамзин 1787 a

[Карамзин Н. М.], Осень, Детское чтение для сердиза и разума, 11, 1787, $193-207$. 1787 б

[Карамзин Н. М.], Весна, Детское чтение для сердиа и разума, 9, 1787, 195-205. 1787в

[Карамзин Н. М.], Зима, Детское чтение для сердиа и разума, 12, 1787, 193-206. $-1791$

Карамзин Н. М., О русских книгах, Московскийжурнал, 2, 1791, 322-325. -1792a

[Карамзин Н. М.], О Досуге. Сочинение Философа Гарве, Московскийжурнал, 6, 1792, 167-176. 
17926

[Карамзин Н. М.], Могила, Московский журнал, 7, 2, 1792, 109-111.

Картина бытия 1798

Картина бытия помышлением созериаемая, или умственное воззрение на драгоценность жизни. Перевод с Англинскаго языка, Москва, 1798.

Кафанова 1989

Кафанова О. Б., Библиография переводов Н.М. Карамзина (1782-1800 гг.), Итоги и проблемы изучения русской литературы XVIII века, 16, Ленинград, 1989, 319-337.

Кох 2007

Кох М., Почеци женског феминистичког есеја у српској књижевности XIX века:

Еустахија Арсић - Милица Стојадиновић Српкиња - Драга Дејановић, Синхронијско и дијахронијско изучавање врста у српској књижевности: зборник, 1, Нови Сад, 2007, 157-169.

2012

Кох М., ...када сазремо као култура... Стваралаштво српскихсписатељища на почетку 20. века (канон - жанр - род), Јелена Јовић, прев., Београд, 2012.

Кулаковский 1903

Кулаковский П. А., Начало Русской школы у Србов: в XVIII веке: очерк из истории русского влияния на юго-славянские литературы, С.-Петербург, 1903.

Левин 1990

Левин Ю. Д., Восприятие английской литературы в России. Ленинград, 1990. 1995

Левин Ю. Д., отв. ред, История русской переводной художественной литературы: Древняя Русъ. XVIII век, 1, С.-Петербург, 1995.

Левитт 2006

Левитт М., «Вечернее размышление о Божием величестве» и «Утреннее размышление о Божием величестве» Ломоносова: опыт определения теологического контекста, XVIII век, 24. С.-Петербург, 2006, 57-70.

Лесковац 1953

Лесковац М., Антологија старије српске поезије, Нови Сад, 1953. 1959

Лесковац М., Ка познавању Еустахија Арсић, Зборник матице спрске за књижност и језик, 6, 1959, 270.

Лещиловская 1989

Лещиловская И. И., Досифей Обрадович и Россия, Русско-сербские литературные связи XVIII - начала XIX века, Москва, 1989.

Лосева 2012

Лосева О. В., Роберт и Клара Шуман: русские пути. К проблеме взаимодействия культур (автореферат диссертации на соискание ученой степени доктора искусствоведения), Москва, 2012.

Лотман 1985

Лотман Ю. М., «Езда в остров любви» Тредиаковского и функция переводной литературы в русской культуре первой половины XVIII века, Проблемы изучения культурного наследия, Москва, 1985, 222-230.

Лош 2014

Лош Т., «Еустахија Арсић - прво женско перо на славеносербском, Вечернъе новости online (http://www.novosti.rs/вести/lifestyle.505.html:521070-Еустахија-Арсић-првоженско-перо-на-славеносербском; дата обращения: 26.06.2019). 
Миланков 2001

Миланков В., Еустахија пл. Арсић и њено доба, Нови Сад, 2001.

Милосављевић 2004

Милосављевић П., Антологија српске поезије: средње доба, Београд, 2004.

Нешумова 2007

Нешумова Т. Ф., Покровский Феофилакт Гаврилович, Русские писатели 1800-1917.

Биографический словарь, 5, Москва, 2007, 26-28.

Николаев 2000

Николаев С. И., Миколай Кохановский в обработке Симеона Полоцкого, Russica Romana, 7, 2000, 11-22.

2004

Николаев С. И., Оригинальность, подражание и плагиат в представлениях русских писателей XVIII века (очерк проблематики), XVIII век, 23, С.-Петербург, 2004, 3-19.

Новаковић 1869

Новаковић С., Српска библијографија за новију књижевност 1741-1867, Биоград, 1869.

Обрадовић 1807

Обрадовић Д., Собраніе разныхъ нравоучителныхъ вещей в ползу и увеселеніе, Будим, 1807.

Огњановић 1891

Огњановић И., Јевстахија пл. Арсићка, рођ. Цинцићева, прва српска списатељица, Јавор, 1891, 87-90.

Павић 1970

Павић М., Историја српске књижевности барокног доба: (XVII i XVIII век), Београд, 1970. 1979

Павић М., Историја српске кньижности класицизма и предромантизма. Класицизам, Београд, 1979.

1991

Павић М., Предромантизам, Београд, 1991.

Панић 2014

Панић Б., Еустахија Арсић - трагови у времену [Eustahija Arsić - urme peste timp; Eustahija Arsić - Traces in Time], Темищварски зборник, 7, Нови Сад, 2014, 63-76. 2015

Панић Б., О стоседамдесетој годишњици смрти. Сећанье на Еустахију Арсић, Банатски алманах, Темишвар, 2015, 66-74.

Петров 1904

Петров Н. И., Исторический взгляд на взаимные отношения между сербами и русскими в образовании и литературе, Известия Отделения русского языка и словесности, 9, 2, 1904, 227-255.

Петровић 1959

Петровић Т., Еустахија Арсић - прва српска списатељица, Зборник матице спрске за књижневност и језик, 6-7, 1959, 62-72.

Позднеев 1971

Позднеев А. В., Неизвестная поэтесса Петровского времени, Русская литература на рубеже двух эпох, Москва, 1971, 277-307.

Приятное и полезное... 1796

Четыре возраста человеческие, Приятное и полезное препровождение времени, 10, 79, 1796, 401-410. 
Радовановић 1972

Радовановић С., Поговор. Српске песникиње од Јефимије до данас. Антологија поезије. Београд, 1972.

1981

Радовановић С., Српске песникиње ХІХ века, Београд, 1981.

2006

Радовановић С., О знаменитим српкињама XIX века, Zemun, 2006

Рак 1998

Рак В. Д., Русские периодические издания XVIII века: Источники. Состав. Приемы компилящии, С.-Петербург, 1998.

Руссов 1826

Руссов С. В., Библиографический каталог Российским писательницам, С.-Петербург, 1826.

Сибинович 1989

Сибинович М., Первые сербские переводы русской поэзии XVIII в., Русско-сербские литературные связи XVIII - начала ХIХ века, Москва, 1989, 25-42.

Симанков 2015

Симанков В. И., Источники журнала «Детское чтение для сердца и разума» (17851789)», XVIII век, 28, Москва, С.-Петербург, 2015, 323-374.

Скерлић 1909

Скерлић Ј., Спрска кньижност у XVIII веку, Београд, 1909.

Сперанский 1904

Сперанский М. Н., Переводные сборники изречений в славяно-русской писъменности. Москва, 1904.

1963

Сперанский М. Н., Рукописные сборники XVIII века: Материалы для истории русской литературы XVIII века, Москва, 1963.

Тихонравов 1898

Тихонравов Н. С., Сочинения, С.-Петербург, 3, 1898.

Толстой 1988

Толстой Н. И., История и структура славянских литературных языков, Москва, 1988.

Топоров 1981

Топоров В. Н., «Сельское кладбище» Жуковского: К истокам русской поэзии, Russian Literature, 10, 1981, 207-282.

Тынянов 1977

Тынянов Ю. Н. Поэтика. История литературы. Кино, Москва, 1977.

Францев 1924

Францев В. А., Державин у славян. Из истории русско-славянских взаимоотношений в ХІХ столетии, Прага, 1924.

Шицгал 1974

Шицгал А. Г., Русский типографский шрифт. Москва, 1974.

Якшичъ 1814

Якшичь Г., Пюснь побпдная на торжественный и всерадостный случай вхожденія союзническихъ войскъ подъ ихъ величествами Імператоромъ Александромъ I всея Россіи..., Будим, 1814.

Якшић 1815

Я[кшић] Г., Ппснъ Ихъ Благородіямъ Господину Савви Арсичу [...] и Его супруги Г. Еvстахіи, яко до нынп первой Списателнищи Сербской, Будим, 1815. 
Alexandrova 2014

Alexandrova N., A Queen of Many Kingdoms: The Autobiography of Rayna Knyagininya, Women Telling Nations, Amelia Sanz, Francesca Scott, Suzan van Dijk, eds., Amsterdam, New York, 2014, 151-67.

Barbier 1822 Barbier M., Dictionnaire des ouvrages Anonymes et Pseudonymes, 1, Paris, 1822

Blas 2014

Blas A. H. de, The Role of Božena Němcová in the Construction of Czech and Slovak Cultural Identity, Women Telling Nations, Amelia Sanz, Francesca Scott, Suzan van Dijk, eds., Amsterdam, New York, 2014, 135-149.

The Critical Review 1791 The Critical Review, 1791, 3.

Cooper 2014 Cooper D. L., Author-translator-forger: Translation and Mystification in Hanka's Prostonárodní Srbská muza and Pushkin's Pěsni zapadnych Slavjan, M. Hrdina, K. Piorecká, eds., Historické fikce a mystifikace v české kultuře 19. Století, Praha, 2014, 59-69.

Curran 2012 Curran M., Atheism, Religion and Enlightenment in Pre-revolutionary Europe, Woodbridge, 2012.

Dojčinović, Pantelić, 2014 Dojčinović B., Pantelić I., Early Modern Women Intellectuals in 19th-Century Serbia: Milica Stojadinović, Draga Dejanović and Milica Tomić, Women Telling Nations, Amelia Sanz, Francesca Scott, Suzan van Dijk, eds., Amsterdam, New York, 2014, 121-133.

Francikova 2017 Francikova D., Women as Essential Citizens in the Czech National Movement: The Making of the Modern Czech Community, Lanham, 2017.

Glagoleva 2003 Glagoleva O., Imaginary World: Reading in the Everyday Life of Russian Provincial Noblewomen, 1750-1825, Women and Gender in 18th-century Russia, Wendy Rosslyn, ed., Ashgate, 2003, 129-146.

Hawkesworth 2000

Hawkesworth, C., Voices in the Shadows: Women and Verbal Art in Serbia and Bosnia, New York, 2000 . 2001

Hawkesworth, C., A History of Central European Women's Writing, New York, 2001.

Kelly 2002

Kelly C., Sappho, Corinna, and Niobe: genres and personae in Russian women's writing, A history of women's writing in Russia, Cambridge, 2002.

Koch 2007 Koch, M., ... kiedy dojrzejemy jako kultura... Twórczość pisarek serbskich na początku XX wieku (kanon-genre-gender), Wrocław, 2007.

Lefevere, Bassnett 1990 Lefevere A., Bassnett S., Translation, History, and Culture. London, New York, 1990.

Macura 1995 Macura V., Znamení zrodu: české národní obrozeníjako kulturnítyp, Praha, 1995.

Nowitzki et al. 2018

Nowitzki H.-P., Roth U., Stiening G., Johann Georg Heinrich Feder (1740-1821): Empirismus und Popularphilosophie zwischen Wolff und Kant, Berlin, Boston, 2018. 
Pirch 1830

Pirch O. von, Reise in Serbien im Späatherbst 1829, 1, Berlin, 1830.

Rosslyn 2000

Rosslyn W., Feats of Agreeable Usefulness: Translations by Russian Women 1763-1825,

Fichtenwalde, 2000.

Thomson 2000

Thomson F. J., The Ages of Man in Slavonic translated and original Literature down to the Time of Peter the Great, Slavica Gandensia, 27, 2000, 247-277.

Stohler 2016

Stohler U., Disrupted Idylls. Nature, Equality, and the Feminine in Sentimentalist Russian Women's Writing (Mariia Pospelova, Mariia Bolotnikova, and Anna Naumova), Frankfurt am Main, Berlin, Bern, Bruxelles, New York, Oxford, Wien, 2016.

Vinitsky 2015

Vinitsky I., Vasily Zhukovsky's Romanticism and the Emotional History of Russia, Evanston, 2015.

Vowels 1994

Vowels J., The "Feminisation" of Russian Literature: Women, Language and Literature in

Eighteenth-Century Russia, Women Writers in Russian Literature, Clyman T. W., Diana Greene

D., eds., Westport, London, 1994, 35-60.

\section{References}

Alexandrova N., A Queen of Many Kingdoms: The Autobiography of Rayna Knyagininya, Women Telling Nations, Amelia Sanz, Francesca Scott, Suzan van Dijk, eds., Amsterdam, New York, 2014, 151-67.

Arsić E., Polezna razmisljanja, Bugarski S., preveo, priredio i dopunske tekstove napisao, Temišvar, 2013.

Blas A. H. de, The Role of Božena Němcová in the Construction of Czech and Slovak Cultural Identity, Women Telling Nations, Amelia Sanz, Francesca Scott, Suzan van Dijk, eds., Amsterdam, New York, 2014, 135-149.

Bugarski S., Milan Ž., Leksikon srba književnika sa današnje teritorije Rumunije 1705-2015, Temišvar, 2016.

Bugarski S., Stepanov Lj., Eustahija Arsić ponovo među nama, Arad kroz vreme: zbornik radova sa međunarodnog naučnog skupa Arad 13-14. septembra 2013, Temišvar, 2014, 105-112.

Cooper D. L., Author-translator-forger: Translation and Mystification in Hanka's Prostonárodní Srbská muza and Pushkin's Pěsni zapadnych Slavjan, M. Hrdina, K. Piorecká, eds., Historické fikce a mystifikace v české kultuře 19. Století, Praha, 2014, 59-69.

Curran M., Atheism, Religion and Enlightenment in Pre-revolutionary Europe, Woodbridge, 2012.

Dobritsyn A., Vechnyi zhanr: zapadnoevropeiskie istoki russkoi epigrammy XVIII - nachala XIX veka, Bern, 2008.

Dojčinović B., Pantelić I., Early Modern Women Intellectuals in 19th-Century Serbia: Milica Stojadi- nović, Draga Dejanović and Milica Tomić, Women Telling Nations, Amelia Sanz, Francesca Scott, Suzan van Dijk, eds., Amsterdam, New York, 2014, 121133.

Doronina R. F., Mushitskii i Derzhavin, Prilozi proučavanju rusko-srpskih književnjih veza XVIII pocetka XIX veka, Moscow, 1989, 145-160.

Dostian I. S., Izdanie i rasprostranenie v Rossii proizvedenii serbskikh avtorov (XVIII - nachalo XIX vv.) Prilozi proučavanju rusko-srpskih književnjih veza XVIII - pocetka XIX veka, Moscow, 1989, 8-24.

Francikova D., Women as Essential Citizens in the Czech National Movement: The Making of the Modern Czech Community, Lanham, 2017.

Frantsev V.A., Derzhavin and the Slavs. On the History of Russian-Slavic Literary Relationships in the 19th Century, Prague, 1924.

Gavrilović S., Iz prepiske sprske književnice Eustihije Arsić, Zbornik matice sprske za knjižnevnost i jezik, 18, 1970, 363-366.

Glagoleva O., Imaginary World: Reading in the Everyday Life of Russian Provincial Noblewomen, 1750-1825, Women and Gender in 18th-century Russia, Wendy Rosslyn, ed., Ashgate, 2003, 129-146.

Gudkov V. P., Osobennosti vosproizvedeniia russkikh tekstov v «Slaveno-serbskom Magazine» pervom serbskom zhurnale, Moscow State University Bulletin. Series 9. Philology, 1, 1977, 57-69.

Gukovsky G. A., Derzhavin's Literary Heritage. A Review Article, Literaturnoe nasledstvo, 9/10, 1933, 369-396. 
Gukovsky G. A., Toward the Problem of Russian Classicism. Competitions and Translations. Rannie raboty po istorii russkoi poezii XVIII veka. Moscow, 2001, 265-269.

Hawkesworth C., A History of Central European Women's Writing, New York, 2001.

Hawkesworth C., Voices in the Shadows: Women and Verbal Art in Serbia and Bosnia, New York, 2000.

Jovićević T., Glas iz potisnutog nasleđa, Knjiženstvo, časopis za studije književnosti, roda i kulture, 4 , 4, 2014, 91-111.

Kafanova O. B., Bibliografiia perevodov N. M. Karamzina (1782-1800 gg.), Itogi i problemy izucheniia russkoi literatury XVIII veka, 16, Leningrad, 1989, 319-337.

Kelly C., Sappho, Corinna, and Niobe: genres and personae in Russian women's writing, A history of women's writing in Russia, Cambridge, 2002.

Koch M., ...kiedy dojrzejemy jako kultura... Twórczość pisarek serbskich na poczatku XX wieku (kanon - genre - gender), Wrocław, 2007.

Koch M., Počeci ženskog feminističkog eseja u srpskoj književnosti XIX veka: Eustahija Arsić Milica Stojadinović Srpkinja - Draga Dejanović, Sinhronijsko i dijahronijsko izučavanje vrsta u srpskoj književnosti: zbornik, 1, Novi Sad, 2007, 157-169.

Koch M., ...kada sazremo kao kultura... Stvaralaštvo srpskih spisateljica na početku XX veka (kanon - žanr - rod), Jelena Jović, prev., Beograd, 2012.

Lefevere A., Bassnett S., Translation, History, and Culture. London, New York, 1990.

Leshchilovskaya I. I., Dosifei Obradovich i Rossiia, Prilozi proučavanju rusko-srpskih književnjih veza XVII - pocetka XIX veka, Moscow, 1989, 64-87.

Leskovac M., Antologija starije srpske poezije, Novi Sad, 1953.

Leskovac M., Ka poznavanju Eustahija Arsić, Zbornik Matice srpske za književnost i jezik, 6, 1959, 270.

Levin Yu. D., ed., The History of Russian Translated Belle lettres: Ancient Russia. 18th century, St. Petersburg, 1995.

Levin Yu. D., Vospriiatie angliiskoi literatury $v$ Rossii, Leningrad, 1990.

Levitt M., "Vechernee razmyshlenie o Bozhiem velichestve" i "Utrennee razmyshlenie o Bozhiem velichestve" Lomonosova: opyt opredeleniia teologicheskogo konteksta, XVIII vek, 24, St. Petersburg, 2006. 57-70.

Lotman Ju. M., "Riding in the Island of Love" by Trediakovsky and the Function of Translated Literature in the Russian Culture of the First Half of the 18th Century, Problemy izucheniia kul'turnogo naslediia, Moscow, 1985, 222-230.

Macura V., Znamení zrodu: české národní obrození jako kulturni typ, Praha, 1995.

Milankov V., Eustahija pl. Arsić i njeno doba, Novi Sad, 2001.
Milosavljević P., Antologija srpske poezije: srednje doba, Beograd, 2004.

Neshumova T. F., Pokrovskii Feofilakt Gavrilovich, Russkie pisateli 1800-1917. Biograficheskii slovar', 5, Moscow, 2007, 26-28.

Nikolaev S. I., Mikolai Kokhanovskii v obrabotke Simeona Polotskogo, Russica Romana, 7, 2000, 11-22.

Nikolaev S. I., Original'nost', podrazhanie i plagiat $\mathrm{v}$ predstavleniiakh russkikh pisatelei XVIII veka (ocherk problematiki), XVIII vek, 23, St. Petersburg, 2004, 3-19.

Nowitzki H.-P., Roth U., Stiening G., Johann Georg Heinrich Feder (1740-1821): Empirismus und Popularphilosophie zwischen Wolff und Kant, Berlin, Boston, 2018.

Panić B., Eustahija Arsić - Traces in Time, Temišvarski zbornik, 7, Novi Sad, 2014, 63-76.

Panić B., O stosedamdesetoj godišnjici smrti. Sećanje na Eustahiju Arsić, Banatski almanah, Temišvar, 2015, 66-74.

Pavić M., Istorija srpske književnosti baroknog doba: (XVII i XVIII vek), Beograd, 1970.

Pavić M., Istorija srpske knjižnosti klasicizma $i$ predromantizma. Klasicizam, Beograd, 1979.

Pavić M., Predromantizam, Beograd, 1991.

Petrović T., Eustahija Arsić - prva srpska spisateljica, Zbornik Matice sprske za knjižnevnost i jezik, 6-7, 1959, 62-72.

Pozdneev A. V., An Unknown Poetess of Peter the Great's Era, Russian literature at the turn of two eras (17th - beginning of 18th centuries), Moscow, 1971, 277-307.

Radovanović S., O znamenitim srpkinjama XIX veka, Zemun, 2006.

Radovanović S., Pogovor. Srpske pesnikinje od Jefimije do danas. Antologija poezije. Beograd, 1972.

Radovanović S., Srpske pesnikinje XIX veka, Beograd, 1981.

Rak V. D., Russian Literary Collections and Periodicals of the Second Half of the 18th Century. Foreign Sources, Composition, Technique, Compilation, St. Petersburg, 1998.

Rosslyn W., Feats of Agreeable Usefulness: Translations by Russian Women 1763-1825, Fichtenwalde, 2000.

Shitsgal A. G., Russkii tipografskii shrift, Moscow, 1974.

Sibinovich M., Pervye serbskie perevody russkoi poezii XVIII v. Prilozi proučavanju rusko-srpskih književnjih veza, Moscow, 1989, 25-42.

Simankov V. I., Istochniki zhurnala "Detskoe chtenie dlia serdtsa i razuma" (1785-1789), XVIII vek, 28, Moscow, St. Petersburg, 2015, 323-374.

Speranskiy M. N., Manuscript Collections of the 18th Century: Materials for the History of Russian Literature of the 18th Century, Moscow, 1963.

Stohler U., Disrupted Idylls. Nature, Equality, and the Feminine in Sentimentalist Russian Women's 
Writing (Mariia Pospelova, Mariia Bolotnikova, and Anna Naumova), Frankfurt am Main, Berlin, Bern, Bruxelles, New York, Oxford, Wien, 2016.

Thomson F. J., The Ages of Man in Slavonic translated and original Literature down to the Time of Peter the Great, Slavica Gandensia, 27, 2000, 247-277.

Tolstoj N. I., Istoriia i struktura slavianskikh literaturnykh iazykov, Moscow, 1988.

Toporov V. N., "A Rural Cemetery" by Zhukovsky: to the Origins of Russian Poetry, Russian Literature, 10, 1981, 207-282.

Tynyanov Yu. N., Poetics. History of Literature. Cinema, Moscow, 1977.

Varga L., Mozaik žitelja Iriških, Novi Sad, 2001.

Vatsuro V. E., The Gothic Novel in Russia, Moscow, 2002.
Vinitsky I., Vasily Zhukovsky's Romanticism and the Emotional History of Russia, Evanston, 2015.

Vowels J., The "Feminisation" of Russian Literature: Women, Language and Literature in Eighteenth-Century Russia, Women Writers in Russian Literature, Clyman T. W., Diana Greene D., eds., Westport, London, 1994, 35-60.

Vuletić V., N. M. Karamzin i literatura serbskogo vozrozhdeniia, Sravnitel'noe izuchenie literatur: Sbornik statei: K 80-letiiu akad. M. P. Alekseeva, Leningrad, 1976, 108-116.

Warda A., Literaturnaia zhizn' Rossii XVIII - nachala XIX veka, Lodz, 2016.

Zorin A. L., The Appearance of the Hero: From the History of Russian Emotional Culture of the Late 18th - Early 19th Centuries, Moscow, 2016.

\section{Ilya Vinitsky}

Doctor of Sciences, Professor of Russian

Department of Slavic Languages and Literatures

Princeton University

241 East Pyne Building

Princeton, NJ 08544

USA

vinitsky@princeton.edu

Received September 14, 2018 